\title{
COVID-19 Pandemic: Advances in Diagnosis, Treatment, Organoid Applications and Impacts on Cancer Patient Management
}

\author{
Chenyang Ye ${ }^{1,2 \dagger}$, Lina Qi ${ }^{1,2 \dagger}$, Ji Wang ${ }^{3,45}$ and Shu Zheng ${ }^{2,6 *}$ \\ ${ }^{1}$ Department of Medical Oncology, The Second Affiliated Hospital of Zhejiang University School of Medicine, Hangzhou, \\ China, ${ }^{2}$ Cancer Institute (Key Laboratory of Cancer Prevention and Intervention, China National Ministry of Education), \\ School of Medicine, The Second Affiliated Hospital, Zhejiang University, Hangzhou, China, ${ }^{3}$ Department of Plastic and \\ Reconstructive Surgery, Zhejiang Provincial People's Hospital, People's Hospital of Hangzhou Medical College, Hangzhou, \\ China, ${ }^{4}$ Department of Surgical Oncology, College of Medicine, Sir Run Run Shaw Hospital, Zhejiang University, Hangzhou, \\ China, ${ }^{5}$ Biomedical Research Center and Key Laboratory of Biotherapy of Zhejiang Province, Hangzhou, China, ${ }^{6}$ Reseach \\ Center for Air Pollution and Health, School of Medicine, Zhejiang University, Hangzhou, China
}

Coronavirus disease 2019 (COVID-19) caused by the novel severe acute respiratory syndrome coronavirus 2 (SARS-CoV-2) has spread globally and rapidly developed into a worldwide pandemic. The sudden outburst and rapid dissemination of SARS-CoV-2, with overwhelming public health and economic burdens, highlight an urgent need to develop effective strategies for the diagnosis and treatment of infected patients. In this review, we focus on the current advances in the diagnostics and treatment for SARS-CoV-2 infection. Notably, we also summarize some antineoplastic drugs repurposed for COVID-19 treatment and address the diagnostic and therapeutic challenges for oncologists to manage cancer patients in this COVID-19 era. In addition, we emphasize the importance of organoid technology as a valuable experimental virology platform to better understand the pathogenesis of COVID-19 and assist rapid screening of drugs against COVID-19.

Keywords: COVID-19, SARS-CoV-2, diagnostics, treatment, cancer patient, organoid

\section{INTRODUCTION}

In December 2019, coronavirus disease 2019 (COVID-19) caused by the novel severe acute respiratory syndrome coronavirus 2 (SARS-CoV-2) emerged as a new world pandemic $(1,2)$. As of 9 January 2021, more than 88.9 million cases and 1.91 million deaths have been reported across 188 countries (3), indicating that the SARS-CoV-2 outbreak has become a serious public health emergency of international concern. Coronaviruses, including four genera (Alpha-, Beta-, Gamma-, and Deltacoronavirus), are enveloped, positive-sense, single-stranded RNA viruses that cause infectious diseases in humans and mammals (4). According to phylogenetic analysis of viral genomes, SARS-CoV-2 is a new member of the Beta coronavirus genus, which also includes severe acute respiratory syndrome coronavirus (SARS-CoV). Viral entry into target cells is facilitated by interactions between the spike (S) protein of coronaviruses and the host cell receptor angiotensin-converting enzyme 2 (ACE2) $(1,5-7)$. Following receptor engagement, the SARS-CoV-2 S protein is primed by cellular serine protease transmembrane protease serine 2 (TMPRSS2) before fusion of the viral and cellular membranes, which is a critical step for the entry and spread of SARS-CoV-2 into host cells $(5,8)$ (Figure 1). 
Since accumulation of SARS-CoV-2 in the respiratory tract is the most serious manifestation, fever and respiratory symptoms, such as cough, shortness of breath, sore throat, etc., are the most common initial symptoms of COVID19 (9). The impact of COVID-19 goes well beyond the respiratory system to influence the heart and vessels. Several clinical studies showed the correlation between COVID-19 and cardiovascular disease $(10,11)$. The presence of preexisting cardiovascular disease is associated with worse prognosis and increased mortality in COVID-19 patients $(9,11,12)$. COVID-19 can result in cardiac and vascular complications including acute cardiac injury, myocardial injury, arrhythmia and venous thromboembolism $(12,13)$. A growing concern over the potential drug-disease interactions in patients with cardiovascular diseases and COVID-19 remains to be solved $(14,15)$. In addition, SAR-CoV-2 also influences other tissues and organs, such as the brain, eyes, nose, liver, kidneys and intestines $(16,17)$ (Figure 1). The damage to these organs may manifest specific symptoms, such as seizure, stroke and brain damage, conjunctivitis, diarrhea, hematuria, and oliguria (9).

Given the vast majority of people are still vulnerable to SARS-CoV-2, the development of strategies to diagnose and treat patients with COVID-19 is urgently needed. In this review, we aim to summarize the clinical manifestations of COVID-19 patients, current advances in diagnostic methods and treatment strategies, and organoid applications to fight against COVID-19. Of note, we focus on some repurposing of antineoplastic drugs for COVID-19 and the diagnostic and therapeutic challenges in the management of cancer patients during the current COVID-19 pandemic.

\section{DIAGNOSTIC STRATEGIES FOR SARS-CoV-2 INFECTION}

Fever and respiratory symptoms are the most common onset symptoms of COVID-19 $(9,18)$. After

\footnotetext{
Abbreviations: COVID-19, Coronavirus disease 2019; SARS-CoV-2, Severe acute respiratory syndrome coronavirus 2; SARS-CoV, Severe acute respiratory syndrome coronavirus; S protein, Spike protein; ACE2, Angiotensin-converting enzyme 2; TMPRSS2, Transmembrane protease serine 2; MERS, Middle East Respiratory Syndrome; ARDS, Acute respiratory distress syndrome; ICU, Intensive care unit; SHERLOCK, Specific high-sensitivity enzymatic reporter unlocking; gRNA, Guide RNA; EUA, Emergency use authorizations; CQ, Chloroquine; HCQ, Hydroxychloroquine; HIV, Immunodeficiency virus; SARS, Severe acute respiratory syndrome; LPV/r, Lopinavir/ritonavir; RBD, Receptor binding domain; hrsACE2, Human recombinant soluble ACE2; CM, Camostat mesylate; AAK1, AP2-associated protein kinase 1; JAK, Janus kinase; IL-6, Interleukin-6; CML, Chronic myelogenous leukemia; GIST, Gastrointestinal stromal tumor; DFSPs, Dermatofibrosarcoma protuberans; ALL, Acute lymphoblastic leukemia; PDGFR, Platelet-derived growth factor receptor; VEGF, Vascular endothelial growth factor; ALI, Acute lung injury; CEA, Carcinoembryonic antigen; CA, Carbohydrate antigens; SCCA, Squamous cell carcinoma antigen; CYFRA21-1, Cytokeratin19 fragment; HuNoV, Human noroviruses; ECM, extracellular matrix; ACTT-1, Adaptive Covid-19 Treatment Trial; FDA, Food and Drug Administration; ECMO, extra-corporal membranous oxygenation; RECOVERY, randomized evaluation of COVID-19 therapy; Ad26, adenovirus type 26; IDSA, Infectious Diseases Society of America; CDC, Centers for Disease Control and Prevention.
}

screening clinical symptoms and epidemiological history, the highly suspected group required laboratory testing or imaging tests to confirm the COVID-19 diagnosis (19).

After the nucleotide sequence of SARS-CoV-2 was identified from patients' respiratory tract samples by Chinese facilities via deep sequencing analysis (20), a series of detection products based on RT-PCR were obtained. The general process was to sample RNA from the upper respiratory tract, extract RNA, and determine whether it was positive after PCR with a specific primer. There are also serological-based tests. In China, some experts proposed the application of CT imaging to diagnose typical cases in epidemic areas (21), but chest CT screening is not suggested for populations with low infection rates because of its low positive predictive value (22) but may be considered a primary tool for the current COVID-19 detection in epidemic areas (23). In addition to nucleic acid PCR testing and serological testing, there are also tests based on other principles, such as antigen-based testing (24), CRISPR-based methods (25), and physics-based methods (26). One of the main advantages of antigen detection is the fast detection speed. However, antigen detection is very specific to viruses but not as sensitive as molecular PCR tests. SHERLOCK SARS-CoV2 is short for Specific High-sensitivity Enzymatic Reporter unLOCKing and is based on Cas13a protease and a guide RNA (gRNA) used to recognize a specific new coronavirus genomic sequence (27). No instrument is required, and a simple test similar to a pregnancy test can quickly detect the presence of a new coronavirus RNA sequence using a Sherlock CRISPR SARS-CoV-2 Kit $(27,28)$. At present, the most widely used detection method is the combination of nasopharyngeal swab nucleic acid PCR and serological IgG/IgM detection (29). Nucleic acid PCR test results are still the gold standard for COVID-19 diagnosis, and serological tests can be used as a supplement (30).

In nucleic acid detection, the sampling site is also critical. The virus can be detected in respiratory, stool, serum (31), urine (32), and sperm samples (33). Saliva or nasopharyngeal swabs are the most convenient to obtain. Doctors use bronchoscopy to sample the lower respiratory tract (34). However, this procedure increases the patient's pain and reduces the efficiency of the test. The kits developed later were mostly nasopharyngeal swabs. At present, there are studies that show that the accuracy of oropharyngeal swab sampling detection may be higher than that of nasopharynx sampling, which further reduces the difficulty of sampling and the patient's pain (35).

As the pandemic began, the requirements for detection time and accuracy were greatly improved. As of 11 May 2020, the FDA had issued 67 individual emergency use authorizations (EUAs) for test kit manufacturers and laboratories for three types of testing (PCR-based testing, serologic testing and antigen testing) (36). The testing time for ID NOW COVID-19 provided by Abbott Laboratories is the shortest at present. Here, we list several typical FDA-approved testing kits and new testing methods in the laboratory stage (Table 1). 


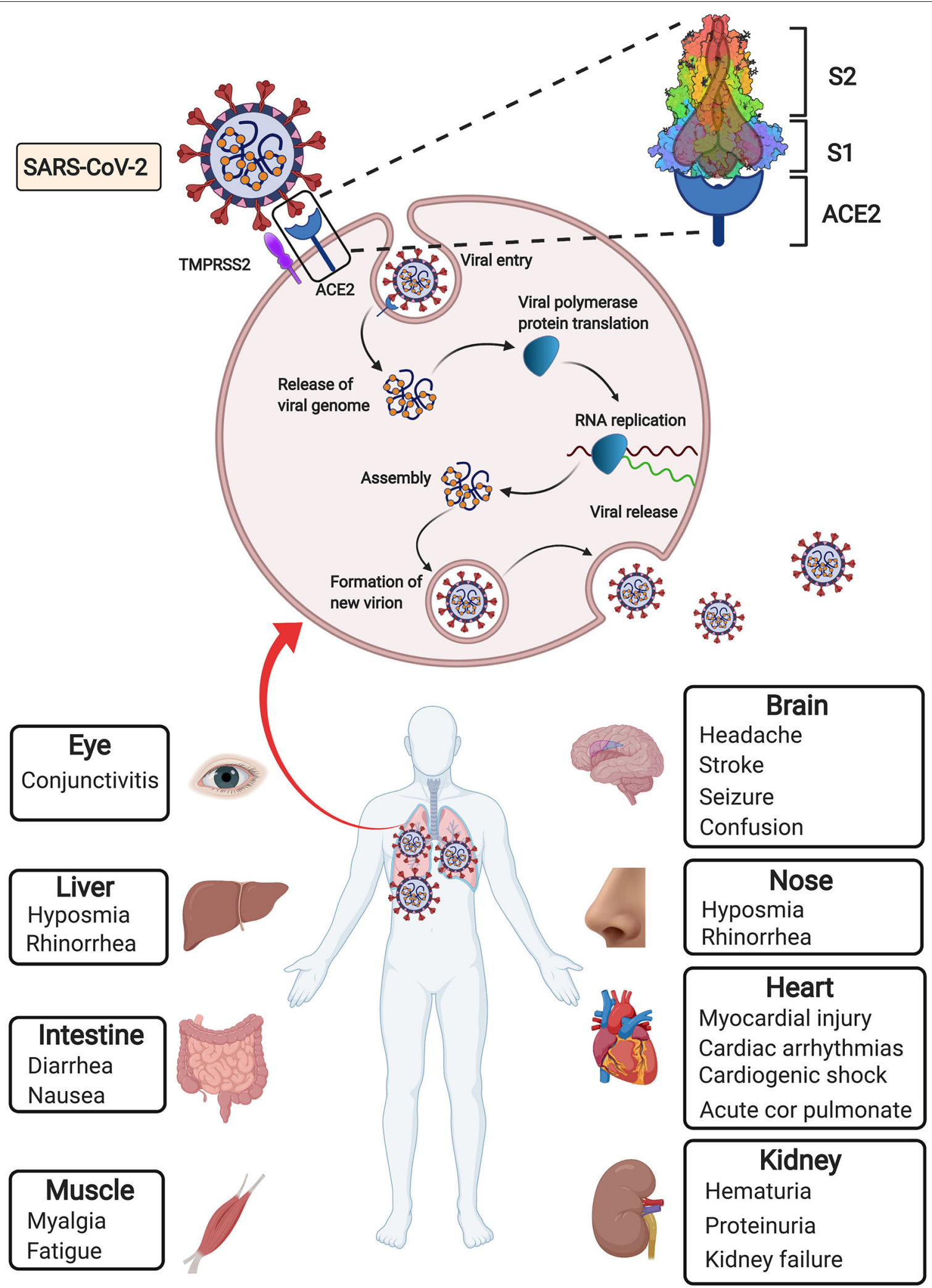

FIGURE 1 | Simplified depiction of SARS-CoV-2 lifecycle and extrapulmonary manifestations of COVID-19. SARS-CoV-2 enters host cells through interaction of its surface spike protein with the ACE2 receptor on the membranes of host cells in the presence of TMPRSS2, which mediates virus-cell membrane fusion and following viral entry. Then viral genomic RNA is released and translated into viral polymerase proteins. Viral RNA is assembled to form mature virions, followed by release of the new virions from the host cells. In addition to the most common pulmonary manifestation of COVID-19, extrapulmonary manifestations derived from many other injured organs have been observed. 
TABLE 1 | Diagnostic methods for COVID-19.

\begin{tabular}{|c|c|c|c|c|c|}
\hline & FDA approved & Institution & Specimen & Testing time & Notes \\
\hline \multicolumn{6}{|l|}{ Virus RNA test } \\
\hline $\begin{array}{l}\text { TaqPath SARS-CoV-2 } \\
\text { Assay }\end{array}$ & YES & $\begin{array}{l}\text { Rutgers Clinical } \\
\text { Genomics Laboratory } \\
\text { (USA) }\end{array}$ & $\begin{array}{l}\text { Oropharyngeal, nasopharyngeal, } \\
\text { anterior nasal, mid-turbinate nasal } \\
\text { swab, saliva }\end{array}$ & n. $r$ & $\begin{array}{l}\text { RT-PCR, can detect } \\
\text { saliva specimen }\end{array}$ \\
\hline $\begin{array}{l}\text { TaqPath }{ }^{\mathrm{TM}} \text { COVID-19 } \\
\text { Combo kit }\end{array}$ & YES & $\begin{array}{l}\text { Thermo Fisher Scientific } \\
\text { (USA) }\end{array}$ & Nasopharynx swab & $4 \mathrm{~h}$ & RT-PCR \\
\hline Cobas $^{\circledR}$ SARS-CoV-2 & YES & Roche (USA) & Nasopharynx swab & $3.5 \mathrm{~h}$ & RT-PCR \\
\hline Xpert Xpress SARS-CoV-2 & YES & Cepheid (USA) & $\begin{array}{l}\text { Nasopharynx swab, nasal wash or } \\
\text { aspiratory specimen }\end{array}$ & $45 \min$ & $\begin{array}{l}\text { RT-PCR, can run up to } \\
2,000 \text { samples per } \\
\text { day }\end{array}$ \\
\hline ID NOW COVID-19 & YES & $\begin{array}{l}\text { Abbott Laboratories } \\
\text { (USA) }\end{array}$ & $\begin{array}{l}\text { Nasopharynx swab } \\
\text { throat swabs }\end{array}$ & $13 \min$ & $\begin{array}{l}\text { ID NOW Instrument } \\
\text { based }\end{array}$ \\
\hline $\begin{array}{l}\text { iLACO (isothermal LAMP } \\
\text { based method for } \\
\text { COVID-19) }\end{array}$ & NO & $\begin{array}{l}\text { Shenyang University } \\
\text { (China) }\end{array}$ & n. $r$ & $20 \mathrm{~min}$ & RT-LAMP \\
\hline $\begin{array}{l}\text { Sherlock CRISPR } \\
\text { SARS-CoV-2 Kit }\end{array}$ & YES & $\begin{array}{l}\text { Sherlock BioSciences, } \\
\text { Inc. (USA) }\end{array}$ & Upper respiratory specimens & $<1 \mathrm{~h}$ & $\begin{array}{l}\text { RT-LAMP+ } \\
\text { CRISPR-Cas13 based }\end{array}$ \\
\hline $\begin{array}{l}\text { CRISPR-based DETECTR } \\
\text { assay }\end{array}$ & NO & $\begin{array}{l}\text { Mammoth Biosciences } \\
\text { (USA) }\end{array}$ & Respiratory swab & $<40$ min & $\begin{array}{l}\text { CRISPR-Cas12- } \\
\text { based, PPV: 95\%, } \\
\text { NPV: } 100 \%\end{array}$ \\
\hline $\begin{array}{l}\text { Dual-Functional } \\
\text { Plasmonic Photothermal } \\
\text { Biosensors }\end{array}$ & NO & $\begin{array}{l}\text { Institute of } \\
\text { Environmental } \\
\text { Engineering } \\
\text { (Switzerland) }\end{array}$ & Respiratory swab & $\approx 17 \min$ & $\begin{array}{l}\text { Plasmonic } \\
\text { photothermal } \\
\text { biosensor based }\end{array}$ \\
\hline SARS-CoV-2 IgG assay & YES & $\begin{array}{l}\text { Abbott Laboratories } \\
\text { (USA) }\end{array}$ & Serum and plasma & $29 \min$ & $\lg G$ \\
\hline $\begin{array}{l}\text { Elecsys }{ }^{\circledR} \text { Anti-SARS-CoV- } \\
2\end{array}$ & YES & Roche (USA) & Serum and plasma & $18 \mathrm{~min}$ & $\begin{array}{l}\operatorname{lgG} \\
\text { Specificity> 99.8\%, } \\
\text { sensitivity } 100 \%\end{array}$ \\
\hline \multicolumn{6}{|l|}{ Antigen } \\
\hline Sofia 2 SARS Antigen FIA & YES & $\begin{array}{l}\text { Quidel Corporation } \\
\text { (USA) }\end{array}$ & Nasopharynx swab & $<15 \min$ & $\begin{array}{l}\text { Test nucleocapsid } \\
\text { protein antigen }\end{array}$ \\
\hline
\end{tabular}

n. $r$, not reported; RT-LAMP, reverse transcriptional loop-mediated isothermal amplification; PPV, Positive predictive value; NPV, Negative predictive value.

\section{THERAPEUTIC STRATEGIES AGAINST COVID-19}

Given the time-consuming process to develop new drugs starting from scratch, several FDA-approved drugs indicated for other diseases have been repurposed to treat COVID-19 because of their antiviral properties. Notably, some antineoplastic medications have also shown capacities for severe COVID19 by mitigating hyperactive immune responses and are now being investigated in ongoing clinical trials (Table 2). Here, we summarize the ongoing therapeutic choices, including antiviral drugs, convalescent plasma therapy, and repurposing antineoplastic medications, that are promising to help us fight against COVID-19. 
TABLE 2 | FDA-approved antineoplastic drugs repurposed for COVID-19 treatment.

\begin{tabular}{|c|c|c|c|}
\hline Antineoplastic drugs & Mechanism of action & $\begin{array}{l}\text { FDA approved cancer-specific } \\
\text { indications }\end{array}$ & COVID-19 clinical trial identifier \\
\hline Tocilizumab & $\begin{array}{l}\text { Binds soluble and membrane bound IL-6 } \\
\text { receptors, preventing IL- } 6 \text { mediated } \\
\text { pro-inflammatory effect }\end{array}$ & Cytokine release syndrome & NCT04361552, NCT04331795 \\
\hline Siltuximab & $\begin{array}{l}\text { Prevents the binding of IL- } 6 \text { to both soluble } \\
\text { and membrane- bound IL- } 6 \text { receptors }\end{array}$ & Multicentric Castleman's disease & NCT04329650, NCT04330638 \\
\hline Imatinib & Multiple tyrosine kinase inhibitor & CML; DFSPS; GIST; ALL; MDS & NCT04357613, NCT04346147 \\
\hline Thalidomide & $\begin{array}{l}\text { Immunomodulatory and antiangiogenic } \\
\text { effect, suppression of tumor necrosis factor- } \alpha\end{array}$ & Multiple myeloma & NCT04273529, NCT04273581 \\
\hline Bevacizumab & $\begin{array}{l}\text { Monoclonal antibody inhibits the binding of } \\
\text { VEGF to its cell surface receptors }\end{array}$ & $\begin{array}{l}\text { Colorectal cancer; Non-squamous } \\
\text { non-small cell lung cancer; } \\
\text { Glioblastoma; cervical cancer; Renal cell } \\
\text { carcinoma }\end{array}$ & NCT04305106, NCT04275414 \\
\hline
\end{tabular}

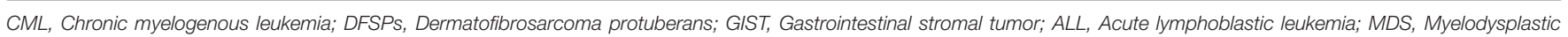
syndrome; VEGF, Vascular endothelial growth factor.

\section{REMDESIVIR}

Remdesivir (GS-5734) is a nucleotide analog prodrug that blocks viral replication by inhibiting viral RNA polymerase (37). The therapeutic effectiveness of remdesivir was first evaluated in both cell-based assays and a rhesus monkey model against Ebola virus, in which remdesivir exhibits potent suppression of viral replication and protection from lethal disease (38). However, the efficacy of remdesivir treatment failed to be proven in a randomized controlled human clinical trial in response to a recent Ebola outbreak in the Democratic Republic of Congo (39). Interestingly, a recent in vitro study indicated that remdesivir has antiviral activity against SARS-CoV-2 (40). In the case report of the first patient with confirmed COVID-19 in the United States, the patient was intravenously administered remdesivir on hospital day 7 based on the patient's worsening clinical status, including persistent fevers and severe pneumonia. On the 8th day, the patient's clinical condition improved without any adverse events related to remdesivir treatment (41). In a small cohort study of patients with severe COVID-19 who underwent compassionate-use remdesivir treatment, improved clinical outcomes were observed in 36 of 53 patients (68\%). However, one clinical trial (ClinicalTrials.gov: NCT04257656) indicated that remdesivir did not exhibit statistically significant clinical benefits compared with those of a placebo (42). But this trial was underpowered due to incomplete full enrollment of eligible patients. The most recent Adaptive Covid-19 Treatment Trial (ACTT-1) was a double-blind, randomized, placebo-controlled trial administrating intravenous remdesivir in 1,062 hospitalized COVID-19 patients (43). The result of this trial showed that remdesivir significantly shortened the time to recovery in COVID-19 patients compared with placebo. However, remdesivir is not routinely recommended in mechanically ventilated COVID-19 patients. Recently, the FDA has approved remdesivir for the treatment of Covid-19 patients requiring hospitalization (44). Because remdesivir alone fails to improve survival rates of COVID-19 patients, several ongoing trials are still awaited to confirm the efficacy and safety of remdesivir combined with modifiers of the immune response for patients with COVID-19 $(43,45)$.

\section{CHLOROQUINE AND HYDROXYCHLOROQUINE}

Chloroquine (CQ) and hydroxychloroquine (HCQ) (an analog of chloroquine) are two well-known medications used for treating malaria and autoimmune diseases, such as rheumatoid arthritis and lupus $(46,47)$. Both CQ and HCQ are able to exhibit broadspectrum antiviral effects by elevating the endosomal/lysosomal $\mathrm{pH}$ essential for virus and host cell fusion $(47,48)$. CQ could also suppress SARS-CoV entry by interfering with the glycosylation of the ACE2 receptor $(47,49,50)$. HCQ is typically preferred over CQ due to its better clinical safety during long-term usage, allowance for higher daily dose, and lower potential for drugdrug interaction $(51,52)$.

Recent in vitro studies showed that both CQ and HCQ can effectively control SARS-CoV-2 infection $(40,53)$. However, in the early stage of the COVID-19 pandemic, there were not enough medical evidence to prove the efficacy of CQ and HCQ treatment for COVID-19, and the results from different small sample studies were controversial (54). Some studies have gained much attention, indicating that HCQ is effective in the treatment of COVID-19 (55, 56). A small open-label non-randomized clinical study from France reported that patients who received $600 \mathrm{mg}$ of HCQ daily had a significant reduction in the viral load. The efficacy of HCQ was reinforced in combination with azithromycin for virus elimination (56). However, the limitations of this study are that comparisons were made between patients at different clinical centers, and six patients (23\%) among the 26 HCQ-treated patients were lost to follow-up due to early cessation of treatment, which weakened the conclusion. The same research group later published another study evaluating the effectiveness of HCQ and azithromycin combination therapy in 80 patients. The results showed that $93 \%$ of treated patients were negative in nasopharyngeal viral load testing after 8 days 
(55). However, this study failed to include a control group. Thus, it is unclear whether patients who did not receive HCQ and azithromycin combination therapy would have similar results. It is noteworthy that a prospective study from France failed to obtain any evidence of obvious clinical benefits or strong antiviral effects upon the combination treatment of HCQ and azithromycin for hospitalized patients with severe COVID-19 (57). In their study, 11 patients received the combination therapy of HCQ and azithromycin. However, eight of 10 patients (one patient was not tested due to death) were still positive for SARSCoV-2 after 6 days. Two patients were transferred to the ICU, and one had to discontinue treatment due to adverse cardiac effects. This study also did not have a control group. Eight of 11 patients had severe comorbidities, including obesity, solid cancer, hematological cancer, and HIV infection, which could be potential confounding effects to influence the results. Similarly, a retrospective study from the U.S. revealed that there was no evidence that therapy with HCQ, either with or without azithromycin, reduced the risk of mechanical ventilation. An association of increased overall death rates was found in patients treated with HCQ alone (58). However, the patients enrolled in this study were all male and over 65 years old (median age), which could introduce bias in this study. In addition, a multicenter, open-label randomized controlled trial including 150 patients in China also concluded that the administration of HCQ did not improve the condition of patients, with a higher negative conversion rate (59). Although the U.S. FDA issued an EUA for the use of HCQ to treat COVID-19 in the United States, the FDA also cautioned against the use of HCQ or CQ for COVID-19 outside of the hospital setting or a clinical trial due to the risk of heart rhythm problems raised by a recent study (60). Therefore, larger high-quality randomized controlled trials are needed to provide a definitive answer regarding the efficacy and safety of this combination. Recently, the controlled, open-label Randomized Evaluation of COVID-19 Therapy (RECOVERY) trial compared the effects between HCQ and usual care in patients hospitalized for COVID19 (61). Unfortunately, patients who received HCQ treatment did not have better clinical outcomes than those who received usual care. The WHO SOLIDARITY trial also released preliminary results on the efficacy of HCQ in hospitalized patients for COVID-19, and the results were in accordance with the ones from the RECOVERY trial (61). Therefore, HCQ is not an effective treatment for hospitalized patients for COVID-19. The living WHO guideline development panel made a strong recommendation against the use of HCQ for people who are not COVID-19 positive (62). But it remains unclear whether HCQ or CQ could be used in mild-to-moderate COVID-19 cases.

\section{LOPINAVIR/RITONAVIR}

Lopinavir, a human immunodeficiency virus (HIV) type 1 aspartate protease inhibitor, was identified as having an in vitro inhibitory effect against SARS-CoV-1 by screening approved drugs for treating severe acute respiratory syndrome (SARS) (6365). Lopinavir is administered in a fixed-dose combination with ritonavir, a potent CYP3A4 inhibitor, to increase the plasma concentration of lopinavir through the inhibition of cytochrome P450 (64, 66). In an open-label clinical study, treatment with a combination of lopinavir/ritonavir and ribavirin reduced the risk of adverse clinical outcomes (ARDS or death) and viral load among patients with SARS compared with that in a historical control group treated with ribavirin only (64). However, the efficacy of lopinavir/ritonavir was difficult to interpret in that study due to lack of randomization and a contemporary control group and the concomitant use of ribavirin and corticosteroid. Lopinavir was also found to have anti-MERS-coronavirus (CoV) activity both in vitro (67) and in a non-human primate animal model (68). Although several clinical case reports indicated that lopinavir/ritonavir (LPV/r)-based combination therapy with ribavirin and interferon alpha led to virological clearance and clinical resolution of infection (69-71), more convincing clinical trial data about the efficacy of this combined therapeutic strategy are needed (71). Therefore, a randomized controlled clinical trial of $L P V / r$ and recombinant interferon- $\beta 1 b$ vs. placebo for MERS is currently under way (ClinicalTrials.gov: NCT02845843) (72). Intriguingly, recent research showed that SARS-CoV-2 leveraged species-specific interferon-driven upregulation of angiotensinconverting enzyme 2 (ACE2) to promote infection (the SARS$\mathrm{CoV}-2$ receptor ACE2 is an interferon-stimulated gene in human airway epithelial cells and is detected in specific cell subsets across tissues). Thus, treatment involving interferon could enhance SARS-CoV-2 infection instead, and caution should be applied in the clinical treatment of patients with COVID-19. For the treatment of severe COVID-19, an open-label, randomized, controlled trial comparing lopinavir/ritonavir (400/100 mg twice daily) $(n=99)$ to standard care $(n=100)$ was performed. The results revealed that lopinavir/ritonavir treatment failed to significantly promote throat viral clearance, facilitate clinical improvement, or reduce mortality in severe COVID-19 patients (66). In addition, one recent study systematically evaluated the clinical characteristics of COVID-19 in patients with liver test abnormalities and found that the use of lopinavir/ritonavir resulted in 4-fold enhanced risk of liver injury (73). The RECOVERY trial is the first large-scale randomized clinical trial to show the effects of lopinavir/ritonavir in patients hospitalized for COVID-19 (74). The result indicated that lopinavir/ritonavir treatment did not reduce duration of hospital stay, risk of progression to invasive mechanical ventilation, or 28-day mortality rate. The interim results of the WHO SOLIDARITY trial also reported that lopinavir-ritonavir did not improve clinical outcomes for COVID-19 patients who require hospitalization (74). Based on the results of recent high quality randomized clinical trials, lopinavir-ritonavir monotherapy is not recommended for patients admitted to hospital with COVID-19.

\section{APN01}

ACE2 has been identified as the key receptor for SARS$\mathrm{CoV}$ both in vitro and in vivo $(75,76)$. ACE2 not only acts as the entry receptor of SARS-CoV but also protects 
against acute lung injury by reducing destructive inflammatory reactions (77). The receptor-binding domain (RBD) of the spike protein of SARS-CoV-2 is very similar to the RBD of SARS$\mathrm{CoV}$, indicating that both viruses possibly use the common host cell receptor ACE2. Recent studies confirmed that the spike protein of SARS-CoV-2 directly contacts ACE2 to enter cells, and SARS-CoV-2 recognizes human ACE2 even more efficiently than SARS-CoV, suggesting an increased capacity of person-to-person SARS-CoV-2 transmission $(6,78,79)$. Treatment with human recombinant soluble ACE2 (hrsACE2) has been proposed to suppress SARS-CoV-2 infections because excessive ACE2 can not only competitively bind with SARS$\mathrm{CoV}-2$ to block the virus from entering the host cells but also protect the lung from injury by recovering cellular ACE2 activity (80). hrsACE2 could effectively inhibit SARS-CoV-2 replication in Vero cells, engineered human blood vessels and kidney organoids (77). Thus, APN01 (hrsACE2) developed by Apeiron Biologics has undergone a placebo-controlled, double-blinded, phase II clinical trial to evaluate its clinical efficacy and safety in the treatment of COVID-19 patients (ClinicalTrials.gov: NCT04335136).

\section{CAMOSTAT MESYLATE}

Camostat mesylate (CM), a serine protease inhibitor of TMPRSS2, was developed in Japan primarily for chronic pancreatitis and postoperative reflux esophagitis (81). Since TMPRSS2 is a serine protease that cleaves and activates the spike protein of SARS-CoV-2, which is vital for SARSCoV-2 entry and viral transmission through interaction with ACE2, CM has become a potential drug candidate for treating COVID-19 (5). Camostat mesylate was validated to inhibit SARS-CoV-2 infection of lung cells, indicating that the host cell entry of SARS-CoV-2 can be effectively inhibited by the clinically proven inhibitor CM. CM is currently undergoing randomized clinical trials (ClinicalTrials.gov: NCT04374019, NCT04355052) that aim to assess whether CM reduces viral entry of SARS-CoV-2 and improves clinical outcomes of patients with COVID-19.

\section{BARICITINIB}

Most viruses enter cells through receptor-mediated endocytosis. One of the pivotal regulators of endocytosis is AP2-associated protein kinase 1 (AAK1) (82). Richardson et al. found, using the BenevolentAI machine learning method, a group of AAK1 inhibitors that could suppress clathrin-mediated endocytosis and thereby impair the ability of the virus to infect cells (83). In this study, baricitinib, a Janus kinase (JAK) inhibitor indicated for the treatment of rheumatoid arthritis (RA) (84), was identified with a particularly high affinity for AAK1. Unlike other AAK1 inhibitors, such as the oncology drugs sunitinib and erlotinib, which have serious side effects at the high doses required to inhibit AAK1 effectively, baricitinib can be administered with once-daily oral dosing and trivial side effects $(83,85)$. In addition, baricitinib has the potential for combination therapy with direct-acting antivirals, such as lopinavir/ritonavir or remdesivir, currently being used and investigated during the COVID-19 pandemic because of its minimal interaction with the relevant cytochrome P450 (CYP) drug-metabolizing enzymes (85). Cantini et al. conducted a pilot study on the safety and clinical efficacy of baricitinib treatment combined with lopinavir-ritonavir in patients with moderate COVID-19 pneumonia (86). However, the limitations of this study, including its open-label, nonrandomized feature, lack of properly designed control group, and limited patient number treated with baricitinib, require larger randomized controlled trials to further demonstrate the efficacy of baricitinib treatment.

\section{CONVALESCENT PLASMA THERAPY}

As a classic passive immunotherapy, convalescent plasma therapy has been used to prevent and treat many infectious diseases since the 1890s (87). Convalescent plasma therapy was successfully applied to the treatment of SARS, H5N1 influenza, 2009 H1N1 pandemic, and MERS, with improved clinical conditions and reduced mortality (88-91). However, in the Ebola virus disease setting, convalescent plasma therapy failed to achieve significant survival improvement (92). Since SARS, MERS, and COVID-19 share similar clinical and virological features (93), convalescent plasma therapy could be a potential treatment alternative for COVID-19 patients (94). One recent laboratory study indicated that sera from several patients can neutralize the COVID-19 virus isolated from the bronchoalveolar lavage fluid of a critically ill patient (1). A systematic review (95) was conducted to assess the clinical efficacy of convalescent plasma therapy for patients with COVID-19. Based on five available clinical studies (87, 96-99), convalescent plasma therapy seems to be promising, with reduced mortality, improved clinical status, and virus clearance. Several randomized clinical trials have been conducted to evaluate the potential benefits of convalescent plasma therapy. $\mathrm{Li}$ et al. found convalescent plasma therapy added to standard treatment failed to result in statistically significant improvement in the time to hospital discharge and clinical improvement within 28 days compared with standard treatment in severe or lifethreatening COVID-19 patients (100). Another randomized trial in COVID-19 patients with severe pneumonia also observed no significant differences in clinical conditions or overall mortality rates between groups treated with convalescent plasma and placebo (101). But it remains unclear whether convalescent plasma treatment works as a treatment for certain COVID19 patients incuding mild-to-moderate COVID-19 cases. The RECOVERY trial (Clinical Trials.gov: NCT04381936), the world's largest trial of convalescent plasma is still recruiting COVID-19 patients who do not require invasive mechanical ventilation or extra-corporal membranous oxygenation (ECMO). The completion of RECOVERY trial may provide further evidence about the effectiveness and safety of convalescent plasma treatment. 


\section{REPURPOSING ANTICANCER MEDICATIONS FOR COVID-19 TREATMENT}

\section{IL-6 or IL-6 Receptor Inhibitors}

Interleukin-6 (IL-6) is upregulated in various solid tumors or hematopoietic malignancies and plays a key role in the initiation and progression of many cancers via the IL-6/JAK/STAT3 pathway (102). Inhibitors targeting IL-6 or the IL-6 receptor have already been used for treating cancers, such as ovarian cancer and metastatic renal cell carcinoma $(103,104)$. In addition, overwhelmingly elevated IL- 6 also plays a central role in cytokine release syndrome (CRS), which can progress quickly to ARDS (105-108). Emerging data indicate that up to $20 \%$ of COVID-19 cases develop into ARDS, which is the main cause of mortality in critical patients with COVID-19 (109, 110). Several studies reported that increased serum IL-6 levels were detected in patients with COVID-19 $(9,18)$ and could serve as an indicator for COVID-19 severity and in-hospital mortality $(19,111,112)$. Thus, targeting the IL-6 signaling pathway is a potential therapeutic strategy to control CRS in COVID-19 patients. Tocilizumab, a humanized monoclonal antibody against the IL-6 receptor is currently being used for treating COVID-19 cases with CRS. In one retrospective study of 21 severe and critical COVID-19 patients, tocilizumab effectively improved clinical symptoms and reduced patient mortality without obvious adverse reactions (113). In another study of 100 consecutive patients with COVID-19 pneumonia and ARDS, tocilizumab produced rapid antihyperinflammatory efficacy and remarkable clinical improvement (114). However, the effectiveness of tocilizumab against CRS in the COVID19 patient setting still needs additional evidence from large randomized, controlled clinical trials. Another humanized antihuman IL-6 receptor monoclonal antibody, sarilumab, and siltuximab, a chimeric antibody targeting IL-6, are currently being evaluated for treating COVID-19 patients with cytokine storm (110). In conclusion, a therapeutic strategy of blocking IL6 or the IL- 6 receptor may be considered a promising choice for the treatment of severe COVID-19 pneumonia and respiratory failure (Table 2).

\section{Imatinib}

Imatinib is an oral anticancer medication used for treating chronic myelogenous leukemia (CML), gastrointestinal stromal tumor (GIST), dermatofibrosarcoma protuberans (DFSPs), and acute lymphoblastic leukemia (ALL) (115). Imatinib plays an inhibitory role in some tyrosine kinase activities, including the oncogenic fusion protein BCR-ABL1 (whose overactivation can result in CML), c-kit (whose mutations are involved in GIST formation), platelet-derived growth factor receptor (PDGFR), and ABL1 kinase (116). In addition, imatinib also displays in vitro antiviral capacities against SARS-CoV and MERS-CoV, which are phylogenetically related to SARS-CoV-2 $(20,117)$. Therefore, imatinib has been postulated to possibly have antiviral function against SARS-CoV-2. In fact, a recent study showed that imatinib binds to the receptor-binding domain (RBD) of SARS-CoV-2 spike protein and inhibits virus replication in vitro, indicating imatinib as a potential repurposed drug candidate for COVID-19 treatment (118). In a clinical case report, a patient with COVID-19 pneumonia displayed clinical improvement after receiving imatinib treatment, whereas the clinical condition deteriorated upon hydroxychloroquine (HCQ) and lopinavir/ritonavir (LPV/r) therapy (119). Currently, several ongoing clinical trials are testing the value of imatinib as a promising treatment option for COVID-19 (Table 2). One clinical trial from France (ClinicalTrials.gov: NCT04357613) aims to assess the use of imatinib in aged hospitalized patients with COVID-19. One randomized double-blind trial from the United States (ClinicalTrials.gov: NCT04357613) is evaluating the safety and efficacy of imatinib compared with placebo for the treatment of hospitalized COVID-19 patients. Another randomized, double-blind, placebo controlled, clinical trial from Netherlands (EudraCT2020-001236-10) tries to investigate whether imatinib prevents pulmonary vascular leak in patients with Covid19.

\section{Thalidomide}

Thalidomide was originally given to expectant mothers to alleviate morning sickness between 1958 and 1962 but was later removed from the market due to its serious teratogenicity (120). However, research on the efficacy of thalidomide in other conditions, including cancer, continued, and thalidomide was recently approved by the FDA for treating multiple myeloma $(121,122)$. In addition, preclinical animal studies showed that thalidomide could alleviate lung injury, with reduced inflammation status and improved survival in mouse models of H1N1 influenza virus infection, indicating the potential therapeutic merit of thalidomide in viral infection (123). Intriguingly, a case report revealed that thalidomide presented an antiviral effect on one patient with COVID-19 (124). The patient with severe COVID-19 received oral thalidomide and low-dose methylprednisolone due to deteriorated clinical manifestations and limited response to other therapies. The patient achieved significant clinical improvement within 1 week of thalidomide treatment (124). However, since this is a single case report, additional clinical studies are needed to confirm the effectiveness of thalidomide and rule out any relevant severe side effects. One clinical trial (ClinicalTrials.gov: NCT04273581) aims to evaluate the efficacy and safety of thalidomide use in combination with low-dose hormones in the treatment of severe COVID19. Another clinical trial (ClinicalTrials.gov: NCT04273529) is investigating the use of thalidomide in the treatment of patients with moderate COVID-19 pneumonia. Currently, these two clinical trials are still underway evaluating thalidomide therapy in patients with moderate or severe COVID-19 (Table 2).

\section{Bevacizumab}

Vascular endothelial growth factor (VEGF) has been identified as a key molecule in the process of endothelial injury and increases microvascular permeability (125). Higher VEGF levels were observed in COVID-19 patients with ARDS than in healthy people (126). Therefore, VEGF is considered a potential therapeutic target in COVID-19 patients with acute lung injury 
(ALI) and ARDS. Bevacizumab, a recombinant humanized antiVEGF monoclonal antibody, is widely used to treat a number of types of solid malignancies, including lung cancer, colon cancer, glioblastoma, and renal-cell carcinoma (127), and is now being evaluated for treating severe or critical patients with COVID-19 pneumonia (Table 2). The result of one clinical trial (ClinicalTrials.gov: NCT04275414) indicated that bevacizumab plus standard care showed remarkable efficacy for treating severe COVID-19 patients (128).

\section{CURRENT DIAGNOSTIC AND THERAPEUTIC CHALLENGES IN CANCER PATIENT CARE DURING THE COVID-19 PANDEMIC}

Due to the current COVID-19 pandemic, healthcare professionals are facing the overwhelming challenges of rapidly increasing new infection cases, not only to effectively cope with the COVID-19 crisis but also to do so without overlooking the care of patients with other diseases, such as cancer. Cancer patients are more vulnerable to COVID-19 infection and more likely to develop serious events than non-cancer COVID-19 patients due to the immunosuppressive state caused by the cancer itself and anticancer treatments (129-131). Specifically, the rates of severe events in COVID-19-infected patients with hematologic cancer, lung cancer, and metastatic cancers were higher than those in patients without cancer (130). Cancer patients who received surgical or chemotherapy treatments exhibited higher mortality rates and a higher possibility of developing critical symptoms $(129,130)$. Thus, it is important for oncologists to determine how to properly diagnose and treat cancer patients in this COVID-19 era.

It can be challenging to diagnose whether cancer patients are infected with COVID-19 because some common symptoms of SARS-CoV-2 infection, including fever, dry cough, and shortness of breath, may also be caused by various kinds of cancer. Patients with central-type lung cancer or multiple lung metastases can develop respiratory distress, which often occurs in severe and critical COVID-19 patients $(132,133)$. Notably, interstitial infiltrate pneumonia displayed by cancer patients who underwent radiotherapy or immune-checkpoint inhibitor treatment could overlap with the symptoms and CT scan characteristics of COVID-19 patients (134-136). Intriguingly, recent studies showed that the levels of some cancer markers, including carcinoembryonic antigen (CEA), carbohydrate antigens (CA) 125 and 153, squamous cell carcinoma antigen (SCCA), and cytokeratin-19 fragment (CYFRA21-1), were elevated in COVID-19 patients and were correlated with the severity of COVID-19 $(137,138)$.

During the COVID-19 epidemic, medical resources focused on combating COVID-19, fear of nosocomial infection and social distancing led to delay of the daily treatment for cancer patients. For uninfected cancer patients, most nonemergency surgery, intravenous chemotherapy and radiotherapy have been suspended (139). Nonetheless, it is pivotal to maintain medical and surgical treatments for cancer patients (140). Modified management including thorough COVID-19 screening for every cancer patient scheduled for operations, reduced hospital stay, and establishment of virtual connection between patients and their relatives can help reduce cross infection and facilitate safe surgical treatments (140). Many oncologists also use online follow-ups, and switch to oral chemotherapy rather than intravenous administration (141). For elective cancer surgery, COVID-19-free surgical pathways were related with lower pulmonary complication rates, SARS-CoV-2 infection rates, and mortality rates compared with no defined pathway (142). The establishment of COVID-19-free surgical pathways, which provides elective surgery, critical care, and inpatient ward care with no shared areas with COVID-19 patients, is paramount during COVID-19 pandemic (142). Of note, Silvia Fiorelli et al. highlighted the importance that lung cancer patients should continue to receive prompt surgical treatment, and upgraded management strategy is needed for the surgical treatment, patient selection and perioperative management (143). Based on appropriate patient screening and improved precautions, no COVID-19 positive cases were recorded among the medical staff or the hospitalized patients during their hospital stay. Their high-volume thoracic surgery center has successfully maintained safe surgical treatment for lung cancer patients (143). For cancer patients with COVID-19 coinfection, whether to continue antitumor therapy is still controversial. A stable lung cancer patient died rapidly with a history of long exposure to nivolumab immunotherapy (144), but it has also been reported that it is safe to continue targeting in mild cases (145). However, because antitumor therapy will further weaken the immune system and the short-term risk brought by COVID-19 is much higher than the risk of tumors, antitumor therapy for COVID-19-positive cancer patients still needs to be very cautious.

\section{APPLICATIONS OF ORGANOID TECHNOLOGY IN COVID-19}

Organoids are 3D structures that can be generated from adult tissue-specific stem cells, embryonic stem cells, or induced pluripotent stem cells and recapitulate pivotal features of original tissues $(146,147)$. Organoids provide unique opportunities for modeling and studying human diseases, including congenital and acquired conditions, to establish paradigms for pathogenesis research, high-throughput drug screening, and living organoid biobanks of specific diseases, facilitating personalized treatments (148-150). Cancer patient-derived organoids have been widely used to investigate the mechanism of tumorigenesis and for personalized medicine approaches (151). More importantly, organoids have proven to be ideal models to investigate infectious diseases and the related pathogenic mechanisms (148). Ettayebi et al. successfully modeled human norovirus ( $\mathrm{HuNoV}$ ) infection and propagation using human small intestinal organoids and identified that bile acts as a critical factor for HuNoV replication (152). Similarly, intestinal, lung, gastric, and brain organoids have been applied to model infectious diseases, including Cryptosporidium (153), Middle East respiratory syndrome coronavirus (154), Helicobacter pylori $(155,156)$, influenza virus 
(157), and Zika virus (158, 159) infections, enabling a better understanding of virus-host interactions, virus pathogenesis and virus transmission.

Currently, limited knowledge of SARS-CoV-2 pathogenesis and transmission is mainly based on clinical features, bioinformatic analysis, and rare autopsy reports $(9,160,161)$, in part due to the lack of appropriate in vitro cell research models that faithfully resemble host tissues. Therefore, human organoids have been recently adopted by several research groups to investigate the mechanisms of SARS-CoV-2 infection and virus-induced tissue damage $(17,77,161,162)$. Human liver ductal organoids were employed to investigate the infection and liver damage of SARS-CoV-2 and have enabled the identification of liver damage caused directly by viral infection (161). Along the same lines, it has been proven that SARS-CoV-2 can readily infect human intestinal enterocytes, and the host cell membranebound serine proteases TMPRSS2 and TMPRSS4 promote the infection process, which indicates that human small intestinal organoids serve as a faithful experimental model for the study of SARS-CoV-2 infection and relevant biology, facilitating future drug testing (17, 162-164). Remarkably, SARS-CoV-2 has been shown to directly infect engineered human blood vessel organoids and kidney organoids, which can be blocked by human recombinant soluble ACE2 (hrsACE2) at early stages of SARS-CoV-2 infection (77).

Since SARS-CoV-2 was reported to affect multiple human organs and the underlying mechanisms are still unclear (16), human organoids of the intestinal, lung, kidney, liver, stomach, retinal, brain, and cardiac systems can be leveraged to study pathogenesis in an organ-specific manner $(146,165)$. In addition, organoid platforms have facilitated personalized drug screening for cancer (146, 166, 167); hence, organoids can also be applied for high-throughput drug screening to discover potential candidates against COVID-19 (Figure 2). Recently, several groups have used organoid-pathogen-immune cell coculture systems to study host-pathogen interactions $(168,169)$. Organoids were infected with microorganisms (viral or bacterial) before culturing together with immune cells in the triple coculture system (170). In this setting, organoids provide great opportunities to probe the interaction between the epithelium, immune system and SARS-CoV-2 and enable potentially new therapeutic targets for treatment. Further organoid studies for dissecting the pathogenesis of COVID-19 are bound to enable improved understanding and potential drug discoveries (Figure 2).

\section{COVID-19 VACCINES}

Vaccination can efficiently elicit human immunity to prevent infection and disease dissemination, thus helping restrain the SARS-CoV-2 crisis. Multiple methods have been used to generate clinical vaccine candidates for SARS-COV-2, including mRNA vaccines, DNA vaccines, viral vector vaccines, and inactivated virus vaccines (171). Several studies have shown promising immune response inductions and no adverse safety events in
Phase III clinical trials (172-175). Currently, over sixty COVID19 vaccines are being tested in clinical trials, with eleven approved for at least limited use (176). Food and Drug Administration (FDA) have granted three highly effective COVID-19 vaccines for EUAs, including two mRNA vaccines from Pfizer-BioNtech and Moderna, and one adenovirus type 26 (Ad26) vaccine from Johnson \& Johnson $(177,178)$. The two mRNA vaccines require two doses, and second dose should be given within 3 weeks of the first dose for the Pfizer-BioNtech vaccine and within 4 weeks for the Moderna vaccine. Both two mRNA vaccines require ultracold storage, making it harder to distribute. The Ad26 vaccine from Johnson \& Johnson is the first single-dose COVID19 vaccine, and has the advantage of being stable at refrigeration temperature (178). Nonetheless, it still takes time for most people to receive the COVID-19 vaccines. And questions also arise around the safety and effectiveness of COVID-19 vaccines in the setting of cancer patients and elderly population. More researches addressing these unclear issues are needed to identify whether cancer patients and elderly people could benefit from COVID vaccines.

\section{LIMITATIONS OF THIS REVIEW}

Several limitations also exist in this review. Firstly, we have cited some preprints in the references, because these papers are still under review or awaiting for publication in official journals. Since these preprints have not been peer reviewed, some interpretations and conclusions from them may need further validation. Secondly, we only discussed the diagnostic and therapeutic challenges in cancer patient care in the COVID19 era. But some patients with autoimmune diseases or organ transplants are also more vulnerable than healthy people. The diagnostic and therapeutic management of these patients is also noteworthy. Lastly, although there are a great number of important papers, ongoing clinical studies and trials, we can only refer to the most important ones in this review based on our limited knowledge.

\section{CONCLUSIONS AND FUTURE PERSPECTIVES}

How to appropriately manage patients with COVID-19 remains a rapidly evolving preventative and therapeutic challenge. And the efficacy and safety of vaccination in cancer patients or elderly people remain unclear. Therefore, doctors are still urgently seeking existing drugs repurposed for treating COVID19. Although several therapeutic agents mentioned above in this review are encouraging for treating patients with COVID-19, the clinical trials evaluating definite efficacy and risk of adverse events are still underway. Several guidelines of COVID-19 including IDSA (Infectious Diseases Society of America) guidelines, WHO living guidance, COVID-19 rapid guideline, and $\mathrm{CDC}$ (Centers for Disease Control and Prevention) guidelines are important references in terms of diagnosis, treatment, prevention of COVID-19 (62, 179-181). In addition, clinical doctors should continually monitor and 


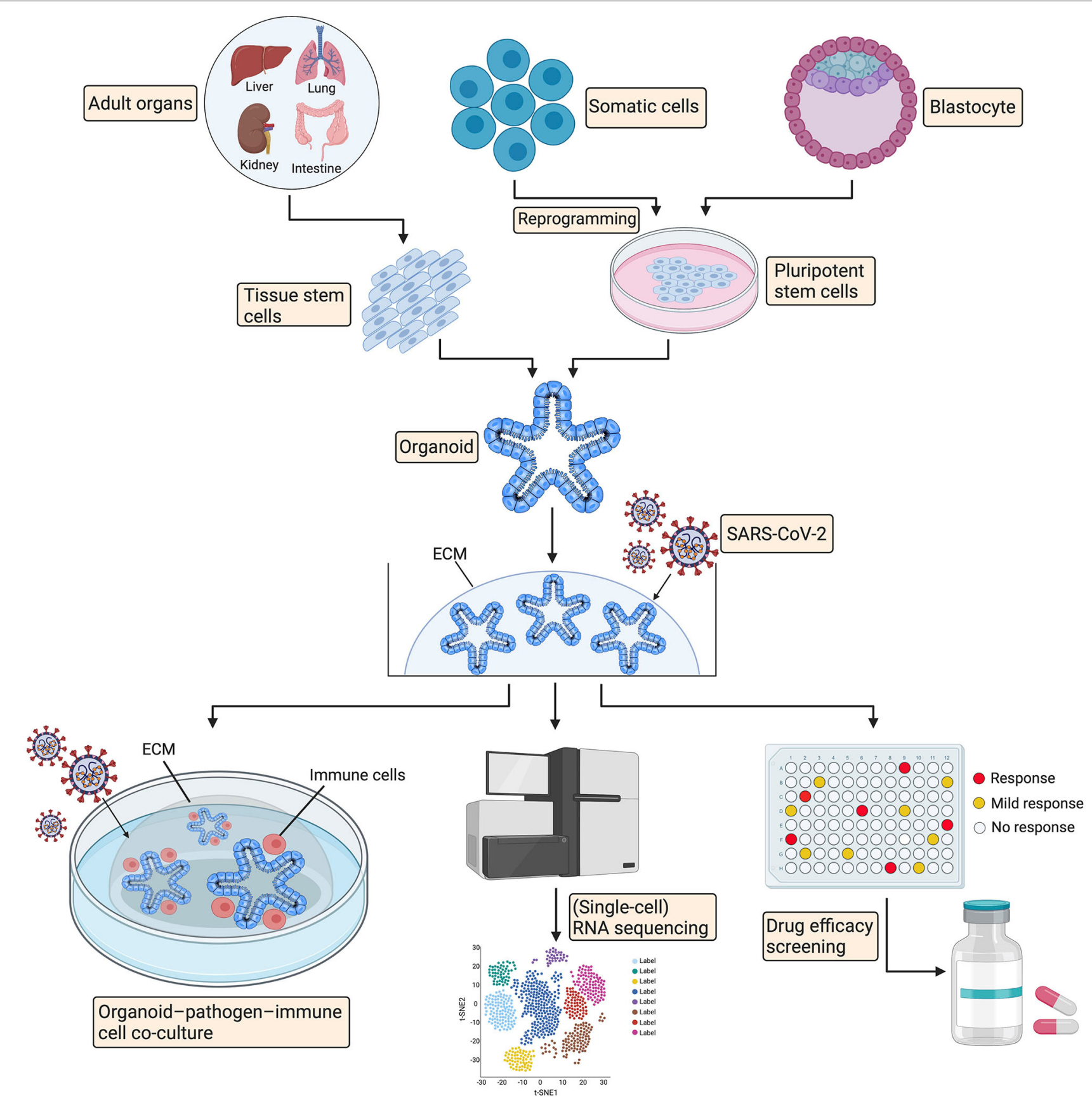

FIGURE 2 | Promising applications of organoid technology in COVID-19. Organoids can be established from adult tissue stem cells, induced pluripotent stem cells, or alternatively, from embryonic stem cells. Organoids can be utilized for pathogenesis investigation via organoid-pathogen-immune cell coculture system and RNA sequencing. Organoids can also facilitate high-throughput drug screening for COVID-19 treatment. ECM, extracellular matrix.

adjust management strategies as new literature becomes available. However, caution should be taken when interpreting the available clinical data, since many studies are uncontrolled and have not been peer reviewed.

The COVID-19 outbreak challenges oncologists to properly protect cancer patients, who are assumed to be vulnerable to SARS-CoV-2 infection, without jeopardizing the management of cancer treatment. However, there are still multiple unknowns about how to manage cancer patients who might be exposed to potential infection or may have been infected with SARSCoV-2. It is important to determine whether COVID-19 would negatively influence active cancer therapies and whether antineoplastic treatments might prevent the cytokine storm caused by SARS-CoV-2. Additionally, data about whether tumor 
stages and disease status have an impact on COVID-19's interactions with cancer and cancer treatments are lacking. Thus, well-designed, multicentered, prospective cohort studies are required to solve these complex COVID-19 puzzles for cancer patients.

Management of highly contagious and potentially fatal COVID-19 has underscored the urgent need to develop efficient diagnosis methods, specific antiviral therapies or vaccines to fight against SARS-CoV-2. In the current era in which cutting-edge technological methods are available, it is pivotal for us to make collaborative efforts to translate basic and innovative science into the discovery of optimal diagnostic and therapeutic options for clinical applications.

\section{REFERENCES}

1. Zhou P, Yang XL, Wang XG, Hu B, Zhang L, Zhang W, et al. A pneumonia outbreak associated with a new coronavirus of probable bat origin. Nature. (2020) 579:270-3. doi: 10.1038/s41586-020-2951-Z

2. Wu F, Zhao S, Yu B, Chen YM, Wang W, Song ZG, et al. A new coronavirus associated with human respiratory disease in China. Nature. (2020) 579:2659. doi: 10.1038/s41586-020-2008-3

3. Dong E, Du H, Gardner L. An interactive web-based dashboard to track COVID-19 in real time. Lancet Infect Dis. (2020) 20:5334. doi: 10.1016/S1473-3099(20)30120-1

4. Weiss SR, Navas-Martin S. Coronavirus pathogenesis and the emerging pathogen severe acute respiratory syndrome coronavirus. Microbiol Mol Biol Rev. (2005) 69:635-64. doi: 10.1128/MMBR.69.4.635-664.2005

5. Hoffmann M, Kleine-Weber H, Schroeder S, Kruger N, Herrler T, Erichsen S, et al. SARS-CoV-2 cell entry depends on ACE2 and TMPRSS2 and is blocked by a clinically proven protease inhibitor. Cell. (2020) 181:27180.e8. doi: 10.1016/j.cell.2020.02.052

6. Walls AC, Park YJ, Tortorici MA, Wall A, McGuire AT, Veesler D. Structure, function, and antigenicity of the SARS-CoV-2 spike glycoprotein. Cell. (2020) 181:281-92.e6. doi: 10.1016/j.cell.2020.02.058

7. Letko M, Marzi A, Munster V. Functional assessment of cell entry and receptor usage for SARS-CoV-2 and other lineage B betacoronaviruses. Nat Microbiol. (2020) 5:562-9. doi: 10.1038/s41564-020-0688-y

8. Matsuyama S, Nao N, Shirato K, Kawase M, Saito S, Takayama I, et al. Enhanced isolation of SARS-CoV-2 by TMPRSS2-expressing cells. Proc Natl Acad Sci USA. (2020) 117:7001-3. doi: 10.1073/pnas.2002589117

9. Huang C, Wang Y, Li X, Ren L, Zhao J, Hu Y, et al. Clinical features of patients infected with 2019 novel coronavirus in Wuhan, China. Lancet. (2020) 395:497-506. doi: 10.1016/S0140-6736(20)30183-5

10. Zheng YY, Ma YT, Zhang JY, Xie X. COVID-19 and the cardiovascular system. Nat Rev Cardiol. (2020) 17:259-60. doi: 10.1038/s41569-020-0360-5

11. Sabatino J, De Rosa S, Di Salvo G, Indolfi C. Impact of cardiovascular risk profile on COVID-19 outcome. A meta-analysis. PLoS ONE. (2020) 15:e0237131. doi: 10.1371/journal.pone.0237131

12. Nishiga M, Wang DW, Han Y, Lewis DB, Wu JC. COVID-19 and cardiovascular disease: from basic mechanisms to clinical perspectives. Nat Rev Cardiol. (2020) 17:543-58. doi: 10.1038/s41569-020-0413-9

13. Sabatino J, Moscatelli S, Rustamova Y, Kotlar I, Avesani M, Brida M, et al. Women's perspective on the COVID-19 pandemic: walking into a post-peak phase. Int J Cardiol. (2021) 323:29-33. doi: 10.1016/j.ijcard.2020.08.025

14. Madjid M, Safavi-Naeini P, Solomon SD, Vardeny O. Potential effects of coronaviruses on the cardiovascular system: a review. JAMA Cardiol. (2020) 5:831-40. doi: 10.1001/jamacardio.2020.1286

15. Driggin E, Madhavan MV, Bikdeli B, Chuich T, Laracy J, Biondi-Zoccai G, et al. Cardiovascular considerations for patients, health care workers, and health systems during the COVID-19 pandemic. J Am Coll Cardiol. (2020) 75:2352-71. doi: 10.1016/j.jacc.2020.03.031

\section{AUTHOR CONTRIBUTIONS}

CY, LQ, and JW conceived this review and collected the literature. $\mathrm{CY}$ and JW drew the schematic diagram. CY and LQ prepared the tables and wrote the manuscript. SZ conducted the study supervision and revised the manuscript. All authors read and approved the final manuscript.

\section{FUNDING}

This work was supported by the National Natural Science Foundation of China (Grant Number 81802883).

16. Wadman M, Couzin-Frankel J, Kaiser J, Matacic C. A rampage through the body. Science. (2020) 368:356-60. doi: 10.1126/science.368.6489.356

17. Lamers MM, Beumer J, van der Vaart J, Knoops K, Puschhof J, Breugem TI, et al. SARS-CoV-2 productively infects human gut enterocytes. Science. (2020) 369:50-4. doi: 10.1126/science.abc1669

18. Chen N, Zhou M, Dong X, Qu J, Gong F, Han Y, et al. Epidemiological and clinical characteristics of 99 cases of 2019 novel coronavirus pneumonia in Wuhan, China: a descriptive study. Lancet. (2020) 395:50713. doi: 10.1016/S0140-6736(20)30211-7

19. Zhou F, Yu T, Du R, Fan G, Liu Y, Liu Z, et al. Clinical course and risk factors for mortality of adult inpatients with COVID-19 in Wuhan, China: a retrospective cohort study. Lancet. (2020) 395:105462. doi: 10.1016/S0140-6736(20)30566-3

20. Lu R, Zhao X, Li J, Niu P, Yang B, Wu H, et al. Genomic characterisation and epidemiology of 2019 novel coronavirus: implications for virus origins and receptor binding. Lancet. (2020) 395:565-74. doi: 10.1016/S0140-6736(20)30251-8

21. Xie X, Zhong Z, Zhao W, Zheng C, Wang F, Liu J. Chest CT for typical 2019-nCoV pneumonia: relationship to negative RT-PCR testing. Radiology. (2020) 296:E41-5. doi: 10.1148/radiol.2020200343

22. Kim H, Hong H, Yoon SH. Diagnostic performance of CT and reverse transcriptase-polymerase chain reaction for coronavirus disease 2019: a meta-analysis. Radiology. (2020) 201343. doi: 10.1148/radiol.2020201343

23. Ai T, Yang Z, Hou H, Zhan C, Chen C, Lv W, et al. Correlation of chest CT and RT-PCR testing in coronavirus disease 2019 (COVID19) in China: a report of 1014 cases. Radiology. (2020) 296:E3240. doi: 10.1148/radiol.2020200642

24. Grant BD, Anderson CE, Williford JR, Alonzo LF, Glukhova VA, Boyle DS, et al. A SARS-CoV-2 coronavirus nucleocapsid antigendetecting half-strip lateral flow assay towards the development of point of care tests using commercially available reagents. Anal Chem. (2020). doi: 10.26434/chemrxiv.12250142

25. Broughton JP, Deng X, Yu G, Fasching CL, Servellita V, Singh J, et al. CRISPR-Cas12-based detection of SARS-CoV-2. Nat Biotechnol. (2020) 38:870-4. doi: 10.1038/s41587-020-0513-4

26. Qiu G, Gai Z, Tao Y, Schmitt J, Kullak-Ublick GA, Wang J. Dualfunctional plasmonic photothermal biosensors for highly accurate severe acute respiratory syndrome coronavirus 2 detection. ACS Nano. (2020) 14:5268-77. doi: 10.1021/acsnano.0c02439

27. Kellner MJ, Koob JG, Gootenberg JS, Abudayyeh OO, Zhang F. SHERLOCK: nucleic acid detection with CRISPR nucleases. Nat Protoc. (2019) 14:29863012. doi: 10.1038/s41596-019-0210-2

28. Joung J, Ladha A, Saito M, Segel M, Bruneau R, Huang MW, et al. Pointof-care testing for COVID-19 using SHERLOCK diagnostics. medRxiv. (2020). doi: 10.1101/2020.05.04.20091231

29. Kevadiya BD, Machhi J, Herskovitz J, Oleynikov MD, Blomberg WR, Bajwa $\mathrm{N}$, et al. Diagnostics for SARS-CoV-2 infections. Nat Mater. (2021). doi: 10.1038/s41563-020-00906-Z 
30. Li Z, Yi Y, Luo X, Xiong N, Liu Y, Li S, et al. Development and clinical application of a rapid IgM-IgG combined antibody test for SARS-CoV-2 infection diagnosis. J Med Virol. (2020) 92:1518-24. doi: 10.1002/jmv.25727

31. Clinical and virologic characteristics of the first 12 patients with coronavirus disease 2019 (COVID-19) in the United States. Nat Med. (2020) 26:8618. doi: 10.1038/s41591-020-0877-5

32. Peng L, Liu J, Xu W, Luo Q, Chen D, Lei Z, et al. SARS-CoV-2 can be detected in urine, blood, anal swabs, and oropharyngeal swabs specimens. J Med Virol. (2020) 92:1676-80. doi: 10.1101/2020.02.21.20026179

33. Li D, Jin M, Bao P, Zhao W, Zhang S. Clinical characteristics and results of semen tests among men with coronavirus disease 2019. JAMA Netw Open. (2020) 3:e208292. doi: 10.1001/jamanetworkopen.2020.8292

34. Xu X, Chen P, Wang J, Feng J, Zhou H, Li X, et al. Evolution of the novel coronavirus from the ongoing Wuhan outbreak and modeling of its spike protein for risk of human transmission. Sci China Life Sci. (2020) 63:457-60. doi: 10.1007/s11427-020-1637-5

35. Wyllie AL, Fournier J, Casanovas-Massana A, Campbell M, Tokuyama M, Vijayakumar P, et al. Saliva or nasopharyngeal swab specimens for detection of SARS-CoV-2. N Engl J Med. (2020) 383:1283-6. doi: 10.1056/NEJMc2016359

36. FDA. Emergency Use Authorization. (2020). Available online at: https://www. fda.gov/emergency-preparedness-and-response/mcm-legal-regulatoryand-policy-framework/emergency-use-authorization

37. Gao Y, Yan L, Huang Y, Liu F, Zhao Y, Cao L, et al. Structure of the RNA-dependent RNA polymerase from COVID-19 virus. Science. (2020) 368:779-82. doi: 10.1126/science.abb7498

38. Warren TK, Jordan R, Lo MK, Ray AS, Mackman RL, Soloveva V, et al. Therapeutic efficacy of the small molecule GS-5734 against Ebola virus in rhesus monkeys. Nature. (2016) 531:381-5. doi: 10.1038/nature17180

39. Mulangu S, Dodd LE, Davey RT Jr, Tshiani Mbaya O, Proschan M, et al. A randomized, controlled trial of ebola virus disease therapeutics. N Engl J Med. (2019) 381:2293-303. doi: 10.1056/NEJMoa1910993

40. Wang $\mathrm{M}$, Cao $\mathrm{R}$, Zhang $\mathrm{L}$, Yang $\mathrm{X}$, Liu $\mathrm{J}, \mathrm{Xu} \mathrm{M}$, et al. Remdesivir and chloroquine effectively inhibit the recently emerged novel coronavirus (2019-nCoV) in vitro. Cell Res. (2020) 30:269-71. doi: 10.1038/s41422-020-0282-0

41. Holshue ML, DeBolt C, Lindquist S, Lofy KH, Wiesman J, Bruce H, et al. First case of 2019 Novel coronavirus in the United States. N Engl J Med. (2020) 382:929-36. doi: 10.1056/NEJMoa2001191

42. Wang Y, Zhang D, Du G, Du R, Zhao J, Jin Y, et al. Remdesivir in adults with severe COVID-19: a randomised, double-blind, placebo-controlled, multicentre trial. Lancet. (2020) 395:156978. doi: 10.1016/S0140-6736(20)31022-9

43. Beigel JH, Tomashek KM, Dodd LE, Mehta AK, Zingman BS, Kalil AC, et al. Remdesivir for the treatment of Covid-19 - final report. N Engl J Med. (2020) 383:1813-26. doi: 10.1056/NEJMoa2007764

44. Rubin D, Chan-Tack K, Farley J, Sherwat A. FDA approval of remdesivir - a step in the right direction. N Engl J Med. (2020) 383:2598600. doi: 10.1056/NEJMp2032369

45. Norrie JD. Remdesivir for COVID-19: challenges of underpowered studies. Lancet. (2020) 395:1525-7. doi: 10.1016/S0140-6736(20)31023-0

46. McChesney EW. Animal toxicity and pharmacokinetics of hydroxychloroquine sulfate. Am J Med. (1983) 75:118. doi: 10.1016/0002-9343(83)91265-2

47. Savarino A, Boelaert JR, Cassone A, Majori G, Cauda R. Effects of chloroquine on viral infections: an old drug against today's diseases? Lancet Infect Dis. (2003) 3:722-7. doi: 10.1016/S1473-3099(03)00806-5

48. Mauthe M, Orhon I, Rocchi C, Zhou X, Luhr M, Hijlkema $\mathrm{KJ}$, et al. Chloroquine inhibits autophagic flux by decreasing autophagosome-lysosome fusion. Autophagy. (2018) 14:143555. doi: 10.1080/15548627.2018.1474314

49. Savarino A, Di Trani L, Donatelli I, Cauda R, Cassone A. New insights into the antiviral effects of chloroquine. Lancet Infect Dis. (2006) 6:679. doi: 10.1016/S1473-3099(06)70361-9

50. Vincent MJ, Bergeron E, Benjannet S, Erickson BR, Rollin PE, Ksiazek TG, et al. Chloroquine is a potent inhibitor of SARS coronavirus infection and spread. Virol J. (2005) 2:69. doi: 10.1186/1743-422X-2-69
51. Yao X, Ye F, Zhang M, Cui C, Huang B, Niu P, et al. In vitro antiviral activity and projection of optimized dosing design of hydroxychloroquine for the treatment of severe acute respiratory syndrome coronavirus 2 (SARS-CoV2). Clin Infect Dis. (2020) 71:732-9. doi: 10.1093/cid/ciaa237

52. Marmor MF, Kellner U, Lai TY, Melles RB, Mieler WF. Recommendations on screening for chloroquine and hydroxychloroquine retinopathy (2016 revision). Ophthalmology. (2016) 123:138694. doi: 10.1016/j.ophtha.2016.01.058

53. Liu J, Cao R, Xu M, Wang X, Zhang H, Hu H, et al. Hydroxychloroquine, a less toxic derivative of chloroquine, is effective in inhibiting SARS-CoV-2 infection in vitro. Cell Discov. (2020) 6:16. doi: 10.1038/s41421-020-0156-0

54. McCreary EK, Pogue JM. Coronavirus disease 2019 treatment: a review of early and emerging options. Open Forum Infect Dis. (2020) 7:ofaa105. doi: 10.1093/ofid/ofaa105

55. Gautret P, Lagier JC, Parola P, Hoang VT, Meddeb L, Sevestre J, et al. Clinical and microbiological effect of a combination of hydroxychloroquine and azithromycin in 80 COVID-19 patients with at least a six-day follow up: a pilot observational study. Travel Med Infect Dis. (2020) 34:101663. doi: 10.1016/j.tmaid.2020.101663

56. Gautret P, Lagier JC, Parola P, Hoang VT, Meddeb L, Mailhe M, et al. Hydroxychloroquine and azithromycin as a treatment of COVID-19: results of an open-label non-randomized clinical trial. Int J Antimicrob Agents. (2020) 56:105949. doi: 10.1016/j.ijantimicag.2020.105949

57. Molina JM, Delaugerre C, Le Goff J, Mela-Lima B, Ponscarme D, Goldwirt L, et al. No evidence of rapid antiviral clearance or clinical benefit with the combination of hydroxychloroquine and azithromycin in patients with severe COVID-19 infection. Med Mal Infect. (2020) 50:384. doi: 10.1016/j.medmal.2020.03.006

58. Magagnoli J, Narendran S, Pereira F, Cummings T, Hardin JW, Sutton SS, et al. Outcomes of hydroxychloroquine usage in United States veterans hospitalized with Covid-19. medRxiv. (2020). doi: 10.1101/2020.04.16.20065920

59. Tang W, Cao Z, Han M, Wang Z, Chen J, Sun W, et al. Hydroxychloroquine in patients with COVID-19: an open-label, randomized, controlled trial. medRxiv. (2020). doi: 10.1101/2020.04.10.20060558

60. Chorin E, Dai M, Shulman E, Wadhwani L, Bar-Cohen R, Barbhaiya C, et al. The QT interval in patients with COVID-19 treated with hydroxychloroquine and azithromycin. Nat Med. (2020) 26:808-9. doi: 10.1101/2020.04.27.20074583

61. Horby P, Mafham M, Linsell L, Bell JL, Staplin N, Emberson JR, et al. Effect of hydroxychloroquine in hospitalized patients with Covid-19. N Engl J Med. (2020) 383:2030-40. doi: 10.1101/2020.06.22.20137273

62. Lamontagne F, Agoritsas T, Siemieniuk R, Rochwerg B, Bartoszko J, Askie L, et al. A living WHO guideline on drugs to prevent covid-19. BMJ. (2021) 372:n526. doi: 10.1136/bmj.n526

63. Wu CY, Jan JT, Ma SH, Kuo CJ, Juan HF, Cheng YS, et al. Small molecules targeting severe acute respiratory syndrome human coronavirus. Proc Natl Acad Sci USA. (2004) 101:10012-7. doi: 10.1073/pnas.0403596101

64. Chu CM, Cheng VC, Hung IF, Wong MM, Chan KH, Chan KS, et al. Role of lopinavir/ritonavir in the treatment of SARS: initial virological and clinical findings. Thorax. (2004) 59:252-6. doi: 10.1136/thorax.2003.012658

65. Chen F, Chan KH, Jiang Y, Kao RY, Lu HT, Fan KW, et al. In vitro susceptibility of 10 clinical isolates of SARS coronavirus to selected antiviral compounds. J Clin Virol. (2004) 31:69-75. doi: 10.1016/S1386-6532(04)00055-1

66. Cao B, Wang Y, Wen D, Liu W, Wang J, Fan G, et al. A trial of lopinavirritonavir in adults hospitalized with severe Covid-19. N Engl J Med. (2020) 382:1787-99. doi: 10.1056/NEJMoa2001282

67. de Wilde AH, Jochmans D, Posthuma CC, Zevenhoven-Dobbe JC, van Nieuwkoop S, Bestebroer TM, et al. Screening of an FDA-approved compound library identifies four small-molecule inhibitors of Middle East respiratory syndrome coronavirus replication in cell culture. Antimicrob Agents Chemother. (2014) 58:4875-84. doi: 10.1128/AAC.03011-14

68. Chan JF, Yao Y, Yeung ML, Deng W, Bao L, Jia L, et al. Treatment with lopinavir/ritonavir or interferon-betalb improves outcome of MERS-CoV infection in a nonhuman primate model of common marmoset. J Infect Dis. (2015) 212:1904-13. doi: 10.1093/infdis/jiv392 
69. Spanakis N, Tsiodras S, Haagmans BL, Raj VS, Pontikis K, Koutsoukou $\mathrm{A}$, et al. Virological and serological analysis of a recent Middle East respiratory syndrome coronavirus infection case on a triple combination antiviral regimen. Int $J$ Antimicrob Agents. (2014) 44:528-32. doi: 10.1016/j.ijantimicag.2014.07.026

70. Kim UJ, Won EJ, Kee SJ, Jung SI, Jang HC. Combination therapy with lopinavir/ritonavir, ribavirin and interferon- $\alpha$ for Middle East respiratory syndrome. Antivir Ther. (2016) 21:455-9. doi: 10.3851/IMP3002

71. Min CK, Cheon S, Ha NY, Sohn KM, Kim Y, Aigerim A, et al. Comparative and kinetic analysis of viral shedding and immunological responses in MERS patients representing a broad spectrum of disease severity. Sci Rep. (2016) 6:25359. doi: 10.1038/srep25359

72. Arabi YM, Alothman A, Balkhy HH, Al-Dawood A, AlJohani S, Al Harbi S, et al. Treatment of Middle East Respiratory Syndrome with a combination of lopinavir-ritonavir and interferon- $\beta 1 \mathrm{~b}$ (MIRACLE trial): study protocol for a randomized controlled trial. Trials. (2018) 19:81. doi: 10.1186/s13063-017-2427-0

73. Cai Q, Huang D, Yu H, Zhu Z, Xia Z, Su Y, et al. Characteristics of liver tests in COVID-19 patients. J Hepatol. (2020) 73. doi: 10.1016/j.jhep.2020.04.006

74. Lopinavir-ritonavir in patients admitted to hospital with COVID-19 (RECOVERY): a randomised, controlled, open-label, platform trial. Lancet. (2020) 396:1345-52. doi: 10.1016/S0140-6736(20)32013-4

75. Imai Y, Kuba K, Rao S, Huan Y, Guo F, Guan B, et al. Angiotensinconverting enzyme 2 protects from severe acute lung failure. Nature. (2005) 436:112-6. doi: 10.1038/nature03712

76. Kuba K, Imai Y, Rao S, Gao H, Guo F, Guan B, et al. A crucial role of angiotensin converting enzyme 2 (ACE2) in SARS coronavirus-induced lung injury. Nat Med. (2005) 11:875-9. doi: 10.1038/nm1267

77. Monteil V, Kwon H, Prado P, Hagelkruys A, Wimmer RA, Stahl $\mathrm{M}$, et al. Inhibition of SARS-CoV-2 infections in engineered human tissues using clinical-grade soluble human ACE2. Cell. (2020) 18:90513.e7. doi: 10.1016/j.cell.2020.04.004

78. Wan Y, Shang J, Graham R, Baric RS, Li F. Receptor recognition by the novel coronavirus from Wuhan: an analysis based on decadelong structural studies of SARS coronavirus. J Virol. (2020) 94:e0012720. doi: 10.1128/JVI.00127-20

79. Wrapp D, Wang N, Corbett KS, Goldsmith JA, Hsieh CL, Abiona O, et al. Cryo-EM structure of the 2019-nCoV spike in the prefusion conformation. Science. (2020) 367:1260-3. doi: 10.1126/science.abb2507

80. Zhang H, Penninger JM, Li Y, Zhong N, Slutsky AS. Angiotensin-converting enzyme 2 (ACE2) as a SARS-CoV-2 receptor: molecular mechanisms and potential therapeutic target. Intensive Care Med. (2020) 46:58690. doi: 10.1007/s00134-020-05985-9

81. Uno Y. Camostat mesilate therapy for COVID-19. Intern Emerg Med. (2020) 1-2. doi: 10.1007/s11739-020-02345-9

82. Conner SD, Schmid SL. Identification of an adaptor-associated kinase, AAK1, as a regulator of clathrin-mediated endocytosis. J Cell Biol. (2002) 156:921-9. doi: 10.1083/jcb.200108123

83. Richardson P, Griffin I, Tucker C, Smith D, Oechsle O, Phelan A, et al. Baricitinib as potential treatment for $2019-\mathrm{nCoV}$ acute respiratory disease. Lancet. (2020) 395:e30-e1. doi: 10.1016/S0140-6736(20)30304-4

84. Bechman K, Subesinghe S, Norton S, Atzeni F, Galli M, Cope AP, et al. A systematic review and meta-analysis of infection risk with small molecule JAK inhibitors in rheumatoid arthritis. Rheumatology. (2019) 58:175566. doi: 10.1093/rheumatology/kez087

85. Stebbing J, Phelan A, Griffin I, Tucker C, Oechsle O, Smith D, et al. COVID19: combining antiviral and anti-inflammatory treatments. Lancet Infect Dis. (2020) 20:400-2. doi: 10.1016/S1473-3099(20)30132-8

86. Cantini F, Niccoli L, Matarrese D, Nicastri E, Stobbione P, Goletti D. Baricitinib therapy in COVID-19: a pilot study on safety and clinical impact. J Infect. (2020) 81:318-56. doi: 10.1016/j.jinf.2020.04.017

87. Duan K, Liu B, Li C, Zhang H, Yu T, Qu J, et al. Effectiveness of convalescent plasma therapy in severe COVID-19 patients. Proc Natl Acad Sci USA. (2020) 117:9490-6. doi: 10.1073/pnas.2004168117

88. Cheng Y, Wong R, Soo YO, Wong WS, Lee CK, Ng MH, et al. Use of convalescent plasma therapy in SARS patients in Hong Kong. Eur J Clin Microbiol Infect Dis. (2005) 24:44-6. doi: 10.1007/s10096-004-1271-9
89. Zhou B, Zhong N, Guan Y. Treatment with convalescent plasma for influenza A (H5N1) infection. N Engl J Med. (2007) 357:14501. doi: 10.1056/NEJMc070359

90. Hung IF, To KK, Lee CK, Lee KL, Chan K, Yan WW, et al. Convalescent plasma treatment reduced mortality in patients with severe pandemic influenza A (H1N1) 2009 virus infection. Clin Infect Dis. (2011) 52:44756. doi: $10.1093 / \mathrm{cid} / \mathrm{ciq} 106$

91. Ko JH, Seok H, Cho SY, Ha YE, Baek JY, Kim SH, et al. Challenges of convalescent plasma infusion therapy in Middle East respiratory coronavirus infection: a single centre experience. Antivir Ther. (2018) 23:617-22. doi: 10.3851/IMP3243

92. van Griensven J, Edwards T, de Lamballerie X, Semple MG, Gallian P, Baize $\mathrm{S}$, et al. Evaluation of convalescent plasma for ebola virus disease in Guinea. N Engl J Med. (2016) 374:33-42. doi: 10.1056/NEJMoa1511812

93. Lee PI, Hsueh PR. Emerging threats from zoonotic coronaviruses-from SARS and MERS to 2019-nCoV. J Microbiol Immunol Infect. (2020) 53:3657. doi: 10.1016/j.jmii.2020.02.001

94. Chen L, Xiong J, Bao L, Shi Y. Convalescent plasma as a potential therapy for COVID-19. Lancet Infect Dis. (2020) 20:398-400. doi: 10.1016/S1473-3099(20)30141-9

95. Rajendran K, Narayanasamy K, Rangarajan J, Rathinam J, Natarajan M, Ramachandran A. Convalescent plasma transfusion for the treatment of COVID-19: systematic review. J Med Virol. (2020) 92:1475-83. doi: 10.1002/jmv.25961

96. Ye M, Fu D, Ren Y, Wang F, Wang D, Zhang F, et al. Treatment with convalescent plasma for COVID-19 patients in Wuhan, China. J Med Virol. (2020) 92:1890-901. doi: 10.1002/jmv.25882

97. Ahn JY, Sohn Y, Lee SH, Cho Y, Hyun JH, Baek YJ, et al. Use of convalescent plasma therapy in two COVID-19 patients with acute respiratory distress syndrome in Korea. J Korean Med Sci. (2020) 35:e149. doi: 10.3346/jkms.2020.35.e149

98. Zhang B, Liu S, Tan T, Huang W, Dong Y, Chen L, et al. Treatment with convalescent plasma for critically ill patients with SARS-CoV-2 infection. Chest. (2020) 158:e9-13. doi: 10.1016/j.chest.2020.03.039

99. Shen C, Wang Z, Zhao F, Yang Y, Li J, Yuan J, et al. Treatment of 5 critically ill patients with COVID-19 with convalescent plasma. JAMA. (2020) 323:15829. doi: 10.1001/jama.2020.4783

100. Li L, Zhang W, Hu Y, Tong X, Zheng S, Yang J, et al. Effect of convalescent plasma therapy on time to clinical improvement in patients with severe and life-threatening COVID-19: a randomized clinical trial. Jama. (2020) 324:460-70. doi: 10.1001/jama.2020.10044

101. Simonovich VA, Burgos Pratx LD, Scibona P, Beruto MV, Vallone MG, Vázquez C, et al. A randomized trial of convalescent plasma in covid-19 severe pneumonia. $N$ Engl J Med. (2020) 384:619-29. doi: 10.1056/NEJMoa2031304

102. Johnson DE, O'Keefe RA, Grandis JR. Targeting the IL6/JAK/STAT3 signalling axis in cancer. Nat Rev Clin Oncol. (2018) 15:234-48. doi: 10.1038/nrclinonc.2018.8

103. Rossi JF, Négrier S, James ND, Kocak I, Hawkins R, Davis H, et al. A phase I/II study of siltuximab (CNTO 328), an anti-interleukin-6 monoclonal antibody, in metastatic renal cell cancer. Br J Cancer. (2010) 103:115462. doi: 10.1038/sj.bjc.6605872

104. Dijkgraaf EM, Santegoets SJ, Reyners AK, Goedemans R, Wouters MC, Kenter GG, et al. A phase I trial combining carboplatin/doxorubicin with tocilizumab, an anti-IL-6R monoclonal antibody, and interferon- $\alpha 2 b$ in patients with recurrent epithelial ovarian cancer. Ann Oncol. (2015) 26:21419. doi: 10.1093/annonc/mdv309

105. Chousterman BG, Swirski FK, Weber GF. Cytokine storm and sepsis disease pathogenesis. Semin Immunopathol. (2017) 39:517-28. doi: 10.1007/s00281-017-0639-8

106. McGonagle D, Sharif K, O'Regan A, Bridgewood C. The role of cytokines including interleukin-6 in COVID-19 induced pneumonia and macrophage activation syndrome-like disease. Autoimmun Rev. (2020) 19:102537. doi: 10.1016/j.autrev.2020.102537

107. Mehta P, McAuley DF, Brown M, Sanchez E, Tattersall RS, Manson JJ. COVID-19: consider cytokine storm syndromes and immunosuppression. Lancet. (2020) 395:1033-4. doi: 10.1016/S0140-6736(20)30628-0 
108. Lee DW, Gardner R, Porter DL, Louis CU, Ahmed N, Jensen M, et al. Current concepts in the diagnosis and management of cytokine release syndrome. Blood. (2014) 124:188-95. doi: 10.1182/blood-2014-05-552729

109. Moore JB, June CH. Cytokine release syndrome in severe COVID-19. Science. (2020) 368:473-4. doi: 10.1126/science.abb8925

110. Konig MF, Powell M, Staedtke V, Bai RY, Thomas DL, Fischer N, et al. Preventing cytokine storm syndrome in COVID-19 using alpha1 adrenergic receptor antagonists. J Clin Invest. (2020) 130:33457. doi: $10.1172 / \mathrm{JCI} 139642$

111. Chen G, Wu D, Guo W, Cao Y, Huang D, Wang H, et al. Clinical and immunological features of severe and moderate coronavirus disease 2019. J Clin Invest. (2020) 130:2620-9. doi: 10.1172/JCI137244

112. Ruan Q, Yang K, Wang W, Jiang L, Song J. Clinical predictors of mortality due to COVID-19 based on an analysis of data of 150 patients from Wuhan, China. Intensive Care Med. (2020) 46:8468. doi: 10.1007/s00134-020-05991-x

113. Xu X, Han M, Li T, Sun W, Wang D, Fu B, et al. Effective treatment of severe COVID-19 patients with tocilizumab. Proc Natl Acad Sci USA. (2020) 117:10970-5. doi: 10.1073/pnas.2005615117

114. Toniati P, Piva S, Cattalini M, Garrafa E, Regola F, Castelli F, et al. Tocilizumab for the treatment of severe COVID-19 pneumonia with hyperinflammatory syndrome and acute respiratory failure: a single center study of 100 patients in Brescia, Italy. Autoimmun Rev. (2020) 19:102568. doi: 10.1016/j.autrev.2020.102568

115. Iqbal N, Iqbal N. Imatinib: a breakthrough of targeted therapy in cancer. Chemother Res Pract. (2014) 2014:357027. doi: 10.1155/2014/357027

116. Bernal-Bello D, Jaenes-Barrios B, Morales-Ortega A, Ruiz-Giardin JM, Garcia-Bermudez V, Frutos-Perez B, et al. Imatinib might constitute a treatment option for lung involvement in COVID-19. Autoimmun Rev. (2020) 19:102565. doi: 10.1016/j.autrev.2020.102565

117. Coleman CM, Sisk JM, Mingo RM, Nelson EA, White JM, Frieman MB. Abelson kinase inhibitors are potent inhibitors of severe acute respiratory syndrome coronavirus and Middle East respiratory syndrome coronavirus fusion. J Virol. (2016) 90:8924-33. doi: 10.1128/JVI.01429-16

118. Mulgaonkar N, Wang H, Mallawarachchi S, Ruzek D, Martina B, Fernando S. Bcr-Abl tyrosine kinase inhibitor imatinib as a potential drug for COVID-19. bioRxiv. (2020). doi: 10.1101/2020.06.18.158196

119. Morales-Ortega A, Bernal-Bello D, Llarena-Barroso C, FrutosPérez B, Duarte-Millán M, de Viedma-García VG, et al. Imatinib for COVID-19: a case report. Clin Immunol. (2020) 218:108518. doi: 10.1016/j.clim.2020.108518

120. Nemer G, Khalil A. A cautious note on thalidomide usage in cancer treatment: genetic profiling of the TBX2 sub-family gene expression is required. Drug Res. (2019) 69:512-8. doi: 10.1055/a-0873-3529

121. Bielenberg DR, D'Amore PA. Judah Folkman's contribution to the inhibition of angiogenesis. Lymphat Res Biol. (2008) 6:203-7. doi: 10.1089/lrb.2008.1016

122. Singhal S, Mehta J, Desikan R, Ayers D, Roberson P, Eddlemon P, et al. Antitumor activity of thalidomide in refractory multiple myeloma. $N$ Engl J Med. (1999) 341:1565-71. doi: 10.1056/NEJM199911183412102

123. Zhu H, Shi X, Ju D, Huang H, Wei W, Dong X. Anti-inflammatory effect of thalidomide on H1N1 influenza virus-induced pulmonary injury in mice. Inflammation. (2014) 37:2091-8. doi: 10.1007/s10753-014-9 943-9

124. Chen C, Qi F, Shi K, Li Y, Li J, Chen Y, et al. Thalidomide combined with low-dose short-term glucocorticoid in the treatment of critical Coronavirus Disease 2019. Clin Transl Med. (2020) 10:e35. doi: 10.1002/ctm2.35

125. Thickett DR, Armstrong L, Christie SJ, Millar AB. Vascular endothelial growth factor may contribute to increased vascular permeability in acute respiratory distress syndrome. Am J Respir Crit Care Med. (2001) 164:16015. doi: $10.1164 /$ ajrccm.164.9.2011071

126. Chi Y, Ge Y, Wu B, Zhang W, Wu T, Wen T, et al. Serum cytokine and chemokine profile in relation to the severity of coronavirus disease 2019 (COVID-19) in China. J Infect Dis. (2020) 222:74654. doi: 10.1093/infdis/jiaa363

127. Mountzios G, Pentheroudakis G, Carmeliet P. Bevacizumab and micrometastases: revisiting the preclinical and clinical rollercoaster. Pharmacol Ther. (2014) 141:117-24. doi: 10.1016/j.pharmthera.2013.09.003
128. Pang J, Xu F, Aondio G, Li Y, Fumagalli A, Lu M, et al. Efficacy and tolerability of bevacizumab in patients with severe Covid-19. medRxiv. (2020). doi: 10.1101/2020.07.26.20159756

129. Liang W, Guan W, Chen R, Wang W, Li J, Xu K, et al. Cancer patients in SARS-CoV-2 infection: a nationwide analysis in China. Lancet Oncol. (2020) 21:335-7. doi: 10.1016/S1470-2045(20)30096-6

130. Dai M, Liu D, Liu M, Zhou F, Li G, Chen Z, et al. Patients with cancer appear more vulnerable to SARS-CoV-2: a multicenter study during the COVID-19 outbreak. Cancer Discov. (2020) 10:78391. doi: 10.1158/2159-8290.CD-20-0422

131. Meng Y, Lu W, Guo E, Liu J, Yang B, Wu P, et al. Cancer history is an independent risk factor for mortality in hospitalized COVID-19 patients: a propensity score-matched analysis. J Hematol Oncol. (2020) 13:75. doi: 10.1186/s13045-020-00907-0

132. Marini JJ, Gattinoni L. Management of COVID-19 respiratory distress. JAMA. (2020) 323:2329-30. doi: 10.1001/jama.2020.6825

133. Lin YC, Tsai YH, Huang CC, Hsu KH, Wang SW, Tsao TC, et al. Outcome of lung cancer patients with acute respiratory failure requiring mechanical ventilation. Respir Med. (2004) 98:43-51. doi: 10.1016/j.rmed.2003.07.009

134. Shi H, Han X, Jiang N, Cao Y, Alwalid O, Gu J, et al. Radiological findings from 81 patients with COVID-19 pneumonia in Wuhan, China: a descriptive study. Lancet Infect Dis. (2020) 20:425-34. doi: 10.1016/S1473-3099(20)30086-4

135. Delaunay M, Cadranel J, Lusque A, Meyer N, Gounant V, MoroSibilot D, et al. Immune-checkpoint inhibitors associated with interstitial lung disease in cancer patients. Eur Respir J. (2017) 50:1700050. doi: 10.1183/13993003.00050-2017

136. Rivera MP, Mehta AC, Wahidi MM. Establishing the diagnosis of lung cancer: diagnosis and management of lung cancer, 3rd ed: American College of Chest Physicians evidence-based clinical practice guidelines. Chest. (2013) 143 (5 Suppl.):e142S-65S. doi: 10.1378/chest.12-2353

137. He B, Zhong A, Wu Q, Liu X, Lin J, Chen C, et al. Tumor biomarkers predict clinical outcome of COVID-19 patients. J Infect. (2020) 81:45282. doi: 10.1016/j.jinf.2020.05.069

138. Wei X, Su J, Yang K, Wei J, Wan H, Cao X, et al. Elevations of serum cancer biomarkers correlate with severity of COVID-19. J Med Virol. (2020). doi: 10.1002/jmv.25957

139. Rosenbaum L. The untold toll - the pandemic's effects on patients without Covid-19. N Engl J Med. (2020) 382:2368-71. doi: 10.1056/NEJMms2009984

140. Maurizi G, Rendina EA. A high-volume thoracic surgery division into the storm of the COVID-19 pandemic. Ann Thorac Surg. (2020) 110:3534. doi: 10.1016/j.athoracsur.2020.03.015

141. Burki TK. Cancer guidelines during the COVID-19 pandemic. Lancet Oncol. (2020) 21:629-30. doi: 10.1016/S1470-2045(20)30217-5

142. Glasbey JC, Nepogodiev D, Simoes JFF, Omar O, Li E, Venn ML, et al. Elective cancer surgery in COVID-19-free surgical pathways during the SARS-CoV-2 pandemic: an international, multicenter, comparative cohort study. J Clin Oncol. (2021) 39:66-78. doi: 10.1200/JCO.20.01933

143. Fiorelli S, Massullo D, Ibrahim M, Piccioni F, Andreetti C, Vanni C, et al. Perspectives in surgical and anaesthetic management of lung cancer in the era of coronavirus disease 2019 (COVID-19). Eur J Cardiothorac Surg. (2020) 58:676-81. doi: 10.1093/ejcts/ezaa295

144. Bonomi L, Ghilardi L, Arnoldi E, Tondini CA, Bettini AC. A rapid fatal evolution of coronavirus disease-19 (COVID-19) in an advanced lung cancer patient with a long time response to nivolumab. J Thorac Oncol. (2020) 15:e83-5. doi: 10.1016/j.jtho.2020.03.021

145. Zhang H, Huang Y, Xie C. The Treatment and Outcome of a Lung Cancer Patient Infected with SARS-CoV-2. J Thorac Oncol. (2020). 15:e63-4. doi: $10.1016 /$ j.jtho. 2020.02 .025

146. Clevers H. Modeling development and disease with organoids. Cell. (2016) 165:1586-97. doi: 10.1016/j.cell.2016.05.082

147. Dutta D, Heo I, Clevers H. Disease modeling in stem cellderived 3D organoid systems. Trends Mol Med. (2017) 23:393410. doi: 10.1016/j.molmed.2017.02.007

148. Lancaster MA, Huch M. Disease modelling in human organoids. Dis Model Mech. (2019) 12:dmm039347. doi: 10.1242/dmm.039347

149. Drost J, Clevers H. Organoids in cancer research. Nat Rev Cancer. (2018) 18:407-18. doi: 10.1038/s41568-018-0007-6 
150. Kopper O, de Witte CJ, Lohmussaar K, Valle-Inclan JE, Hami $\mathrm{N}$, Kester L, et al. An organoid platform for ovarian cancer captures intra- and interpatient heterogeneity. Nat Med. (2019) 25:838-49. doi: 10.1038/s41591-019-0422-6

151. Tuveson D, Clevers H. Cancer modeling meets human organoid technology. Science. (2019) 364:952-5. doi: 10.1126/science.aaw6985

152. Ettayebi K, Crawford SE, Murakami K, Broughman JR, Karandikar U, Tenge $\mathrm{VR}$, et al. Replication of human noroviruses in stem cell-derived human enteroids. Science. (2016) 353:1387-93. doi: 10.1126/science.aaf5211

153. Heo I, Dutta D, Schaefer DA, Iakobachvili N, Artegiani B, Sachs N, et al. Modelling Cryptosporidium infection in human small intestinal and lung organoids. Nat Microbiol. (2018) 3:814-23. doi: 10.1038/s41564-018-0177-8

154. Zhou J, Li C, Zhao G, Chu H, Wang D, Yan HH, et al. Human intestinal tract serves as an alternative infection route for Middle East respiratory syndrome coronavirus. Sci Adv. (2017) 3:eaao4966. doi: 10.1126/sciadv.aao4966

155. Bartfeld S, Bayram T, van de Wetering M, Huch M, Begthel H, Kujala $\mathrm{P}$, et al. In vitro expansion of human gastric epithelial stem cells and their responses to bacterial infection. Gastroenterology. (2015) 148:12636.e6. doi: 10.1053/j.gastro.2014.09.042

156. McCracken KW, Cata EM, Crawford CM, Sinagoga KL, Schumacher $\mathrm{M}$, Rockich BE, et al. Modelling human development and disease in pluripotent stem-cell-derived gastric organoids. Nature. (2014) 516:4004. doi: 10.1038/nature 13863

157. Zhou J, Li C, Sachs N, Chiu MC, Wong BH, Chu H, et al. Differentiated human airway organoids to assess infectivity of emerging influenza virus. Proc Natl Acad Sci USA. (2018) 115:6822-7. doi: 10.1073/pnas.1806308115

158. Watanabe M, Buth JE, Vishlaghi N, de la Torre-Ubieta L, Taxidis J, Khakh BS, et al. Self-organized cerebral organoids with human-specific features predict effective drugs to combat zika virus infection. Cell Rep. (2017) 21:517-32. doi: 10.1016/j.celrep.2017.09.047

159. Garcez PP, Loiola EC, Madeiro da Costa R, Higa LM, Trindade P, Delvecchio $\mathrm{R}$, et al. Zika virus impairs growth in human neurospheres and brain organoids. Science. (2016) 352:816-8. doi: 10.1126/science.aaf6116

160. Xu Z, Shi L, Wang Y, Zhang J, Huang L, Zhang C, et al. Pathological findings of COVID-19 associated with acute respiratory distress syndrome. Lancet Respir Med. (2020) 8:420-2. doi: 10.1016/S2213-2600(20) 30076-X

161. Zhao B, Ni C, Gao R, Wang Y, Yang L, Wei J, et al. Recapitulation of SARS-CoV-2 infection and cholangiocyte damage with human liver ductal organoids. Protein Cell. (2020) 11:771-75. doi: 10.1101/2020.03.16. 990317

162. Zhou J, Li C, Liu X, Chiu MC, Zhao X, Wang D, et al. Infection of bat and human intestinal organoids by SARS-CoV-2. Nat Med. (2020) 26:107783. doi: 10.1038/s41591-020-0912-6

163. Zang R, Gomez Castro MF, McCune BT, Zeng Q, Rothlauf PW, Sonnek NM, et al. TMPRSS2 and TMPRSS4 promote SARS-CoV-2 infection of human small intestinal enterocytes. Sci Immunol. (2020) 5:eabc3582. doi: 10.1126/sciimmunol.abc3582

164. Mulay A, Konda B, Garcia G, Yao C, Beil S, Sen C, et al. SARS-CoV-2 infection of primary human lung epithelium for COVID-19 modeling and drug discovery. bioRxiv. (2020). doi: 10.1101/2020.06.29.174623

165. Dutta D, Clevers H. Organoid culture systems to study hostpathogen interactions. Curr Opin Immunol. (2017) 48:1522. doi: 10.1016/j.coi.2017.07.012

166. Broutier L, Mastrogiovanni G, Verstegen MM, Francies HE, Gavarró LM, Bradshaw CR, et al. Human primary liver cancer-derived organoid cultures for disease modeling and drug screening. Nat Med. (2017) 23:142435. doi: $10.1038 / \mathrm{nm} .4438$
167. Fan H, Demirci U, Chen P. Emerging organoid models: leaping forward in cancer research. J Hematol Oncol. (2019) 12:142. doi: 10.1186/s13045-019-0832-4

168. Sachs N, Papaspyropoulos A, Zomer-van Ommen DD, Heo I, Böttinger L, Klay D, et al. Long-term expanding human airway organoids for disease modeling. EMBO J. (2019) 38:e100300. doi: 10.15252/embj.2018100300

169. Holokai L, Chakrabarti J, Broda T, Chang J, Hawkins JA, Sundaram $\mathrm{N}$, et al. Increased programmed death-ligand 1 is an early epithelial cell response to helicobacter pylori infection. PLoS Pathog. (2019) 15:e1007468. doi: 10.1371/journal.ppat.1007468

170. Bar-Ephraim YE, Kretzschmar K, Clevers H. Organoids in immunological research. Nat Rev Immunol. (2020) 20:27993. doi: 10.1038/s41577-019-0248-y

171. Amanat F, Krammer F. SARS-CoV-2 vaccines: status report. Immunity. (2020) 52:583-9. doi: 10.1016/j.immuni.2020.03.007

172. Jackson LA, Anderson EJ, Rouphael NG, Roberts PC, Makhene M, Coler RN, et al. An mRNA vaccine against SARS-CoV-2 - preliminary report. $N$ Engl Med. (2020) 383:1920-31. doi: 10.1056/NEJMoa2022483

173. Zhu FC, Li YH, Guan XH, Hou LH, Wang WJ, Li JX, et al. Safety, tolerability, and immunogenicity of a recombinant adenovirus type- 5 vectored COVID19 vaccine: a dose-escalation, open-label, non-randomised, first-in-human trial. Lancet. (2020) 395:1845-54. doi: 10.1016/S0140-6736(20)31208-3

174. Polack FP, Thomas SJ, Kitchin N, Absalon J, Gurtman A, Lockhart S, et al. Safety and efficacy of the BNT162b2 mRNA Covid-19 vaccine. $N$ Engl J Med. (2020) 383:2603-15. doi: 10.1056/NEJMoa2034577

175. Baden LR, El Sahly HM, Essink B, Kotloff K, Frey S, Novak R, et al. Efficacy and safety of the mRNA-1273 SARS-CoV-2 vaccine. N Engl J Med. (2020) 384:403-16. doi: 10.1056/NEJMoa2035389

176. Hwang JK, Zhang T, Wang AZ, Li Z. COVID-19 vaccines for patients with cancer: benefits likely outweigh risks. J Hematol Oncol. (2021) 14:38. doi: 10.1186/s13045-021-01046-w

177. Banerji A, Wickner PG, Saff R, Stone CA Jr, Robinson LB, et al. mRNA vaccines to prevent COVID-19 disease and reported allergic reactions: current evidence and approach. J Allergy Clin Immunol Pract. (2020). doi: 10.1016/j.jaip.2020.12.047

178. Livingston EH, Malani PN, Creech CB. The Johnson \&amp; Johnson Vaccine for COVID-19. JAMA. (2021). doi: 10.1001/jama.2021.2927

179. Dugar SP, Vallabhajosyula S. IDSA made 4 strong recommendations for preventing COVID-19 infection in health care personnel. Ann Intern Med. (2021) 174:Jc14. doi: 10.7326/ACPJ202102160-014

180. Jernigan DB. Update: public health response to the coronavirus disease 2019 outbreak - United States, February 24, 2020. MMWR Morb Mortal Wkly Rep. (2020) 69:216-9. doi: 10.15585/mmwr.mm6908e1

181. National Institute for Health and Care Excellence: Clinical Guidelines. COVID-19 Rapid Guideline: Managing the Long-Term Effects of COVID-19. London: National Institute for Health and Care Excellence (UK) Copyright (C) NICE 2020 (2020)

Conflict of Interest: The authors declare that the research was conducted in the absence of any commercial or financial relationships that could be construed as a potential conflict of interest.

Copyright (c) 2021 Ye, Qi, Wang and Zheng. This is an open-access article distributed under the terms of the Creative Commons Attribution License (CC BY). The use, distribution or reproduction in other forums is permitted, provided the original author(s) and the copyright owner(s) are credited and that the original publication in this journal is cited, in accordance with accepted academic practice. No use, distribution or reproduction is permitted which does not comply with these terms. 